\title{
Facilitating Conservation and Bridging Gaps for the Sustainable Exploitation of the Tunisian Local Endemic Plant Marrubium aschersonii (Lamiaceae)
}

\author{
Elias Pipinis ${ }^{1,+}$, Stefanos Hatzilazarou ${ }^{2,+} \mathbb{D}$, Stefanos Kostas ${ }^{2,+}\left(\mathbb{D}\right.$, Soumaya Bourgou ${ }^{3, *(\mathbb{D})}$, \\ Wided Megdiche-Ksouri ${ }^{3}$, Zeineb Ghrabi-Gammar 4,5, Mohamed Libiad 6,7 (D), Abdelmajid Khabbach 6,8 (D), \\ Mohamed El Haissoufi ${ }^{6}$, Fatima Lamchouri ${ }^{6}{ }^{D}$, Emmanouil Koundourakis ${ }^{2}$, Vasileios Greveniotis ${ }^{9}$, \\ Evgenia Papaioannou ${ }^{10}\left(\mathbb{D}\right.$, Michalia A. Sakellariou ${ }^{11}$, Ioannis Anestis ${ }^{11}\left(\mathbb{D}\right.$, Georgios Tsoktouridis ${ }^{11,12} \mathbb{D}$ \\ and Nikos Krigas 11,*(D)
}

check for updates

Citation: Pipinis, E.; Hatzilazarou, S.; Kostas, S.; Bourgou, S.;

Megdiche-Ksouri, W.;

Ghrabi-Gammar, Z.; Libiad, M.;

Khabbach, A.; El Haissoufi, M.;

Lamchouri, F.; et al. Facilitating Conservation and Bridging Gaps for the Sustainable Exploitation of the Tunisian Local Endemic Plant Marrubium aschersonii (Lamiaceae). Sustainability 2022, 14, 1637. https://doi.org/10.3390/su14031637 Academic Editor: Sara Magrini Received: 31 December 2021 Accepted: 27 January 2022 Published: 30 January 2022 Publisher's Note: MDPI stays neutral with regard to jurisdictional claims in published maps and institutional affiliations.

Copyright: (C) 2022 by the authors. Licensee MDPI, Basel, Switzerland. This article is an open access article distributed under the terms and conditions of the Creative Commons Attribution (CC BY) license (https:// creativecommons.org/licenses/by/ $4.0 /)$.
1 Laboratory of Silviculture, School of Forestry and Natural Environment, Aristotle University of Thessaloniki, 54124 Thessaloniki, Greece; epipinis@for.auth.gr

2 Laboratory of Floriculture, School of Agriculture, Aristotle University of Thessaloniki, 54124 Thessaloniki, Greece; hatzilaz@agro.auth.gr (S.H.); skostas@agro.auth.gr (S.K.); ekoundou@agro.auth.gr (E.K.)

3 Laboratoire des Plantes Aromatiques et Médicinales, Centre de Biotechnologie de Borj-Cédria, B.P. 901, Tunis 2050, Tunisia; ksouriwided@yahoo.fr

4 Institut National Agronomique de Tunisie, Université de Carthage, 43 Avenue Charles Nicolle, Cité Mahrajène, Tunis 1082, Tunisia; zghrabi@yahoo.fr

5 Laboratoire de Recherche Biogéographie, Climatologie Appliquée et Dynamiques Environnementales (BiCADE 18ES13), Faculté des Lettres des Arts et des Humanités de Manouba, Université de la Manouba, Campus Universitaire de la Manouba, Manouba 2010, Tunisia

6 Laboratory of Natural Substances, Pharmacology, Environment, Modelling, Health and Quality of Life (SNAMOPEQ), Polydisciplinary Faculty of Taza, Sidi Mohamed Ben Abdellah University, B.P. 1223, Taza Gare, Taza 35000, Morocco; libiad001@gmail.com (M.L.); khamajid@hotmail.com (A.K.); mohamed.elhaissoufi1@usmba.ac.ma (M.E.H.); fatima.lamchouri@usmba.ac.ma (F.L.)

7 Laboratory of Ecology, Systematics and Biodiversity Conservation (LESCB) URL-CNRST N ${ }^{\circ} 18$, FS, Abdelmalek Essaadi University, BP. 2121, M'Hannech II, Tetouan 93002, Morocco

8 Laboratory of Biotechnology, Conservation and Development of Natural Resources (BCVRN), Department of Biology, Faculty of Sciences Dhar El Mahraz, Sidi Mohamed Ben Abdellah University, B.P. 1796, Fès-Atlas 30003, Morocco

9 Institute of Industrial and Forage Crops, Hellenic Agricultural Organization Demeter, 41335 Larisa, Greece; vgreveni@mail.com

10 Laboratory of Forest Soil Science, School of Forestry and Natural Environment, Aristotle University of Thessaloniki, 54124 Thessaloniki, Greece; eapapaioa@agro.auth.gr

11 Institute of Plant Breeding and Genetic Resources, Hellenic Agricultural Organization Demeter, P.O. Box 60458, 57001 Thermi, Greece; michsakellariou@yahoo.com (M.A.S.); ganestis3@gmail.com (I.A.); gtsok1@yahoo.co.uk (G.T.)

12 Theofrastos Fertilizers, Industrial Area of Korinthos, Irinis \& Filias, Ikismos Arion, Examilia, 20100 Korinthos, Greece

* Correspondence: bourgousoumaya@yahoo.com (S.B.); nikoskrigas@gmail.com (N.K.); Tel.: +30-2310-471110 (N.K.)

$+\quad$ These authors contributed equally to this work.

Abstract: In the frame of conservation and sustainable utilization of neglected and underutilized phytogenetic resources, this study produced for the first time a detailed ecological profiling for the local Tunisian endemic Marrubium ascheronii (Lamiaceae) using Geographical Information Systems and open-source data. This profile was used to illustrate the abiotic environmental conditions of its wild habitats; the profile facilitated the examination of the effect of temperature on its seed germination and may inform species-specific guidelines for its cultivation in man-made environments. With effective seed propagation firstly reported herein $\left(68.75 \%\right.$ at $\left.20{ }^{\circ} \mathrm{C}\right)$, species-specific in situ conservation efforts and ex situ conservation or sustainable exploitation strategies were enabled for M. aschersonii. The first-reported molecular authentication (DNA barcoding) of $M$. aschersonii may facilitate its traceability, allowing for product design. This study also reports for the first time the 
effects of chemical and integrated nutrient management (INM) fertilizers on the growth and pilot cultivation of $M$. aschersonii seedlings, with the latter being advantageous. This multidisciplinary approach has bridged important research gaps that hindered the conservation efforts and/or the sustainable exploitation for this local endemic plant of Tunisia. Based on all the above, we re-evaluated and updated the feasibility and readiness timescale for sustainable exploitation of M. aschersonii in the medicinal-cosmetic, agro-alimentary and ornamental-horticultural sectors.

Keywords: African biodiversity; seed germination; GIS; DNA barcoding; integrated nutrient management; chlorophyll content; nutrient content

\section{Introduction}

The genus Marrubium (Lamiaceae) includes about 40 recognized species mainly distributed in Europe, North Africa, and Asia [1]. Phylogenetic studies of the genus Marrubium to evaluate the current generic classification of tribe Marrubieae are required to define explicitly the genus limits [2]. Previous research has been conducted very early in attempts to characterize the Tribe Marrubieae using the chloroplast $r b c L$ gene [3]. Single nucleotide polymorphisms (SNPs) have been extensively used for three species of Marrubium using the ITS and $r b c \mathrm{~L}$ molecular markers [4]; the chloroplast markers $m a t \mathrm{~K}, \operatorname{trn} \mathrm{L}, \operatorname{trn} \mathrm{L}-\operatorname{trn} \mathrm{F}$, and rps 16 for five species of Marrubium [5,6]; and finally the most complete phylogenetic approach using 36 accessions representing 27 species of Marrubium applying the ITS of nrDNA and $r p l 32-t r n \mathrm{~L}, t r n \mathrm{~L}, t r n \mathrm{~L}-t r n \mathrm{~F}$ and $r p s 16$ of cpDNA molecular markers [2]. There is also a RAPD profiling for M. alysson L. and M. vulgare L. [7] and ISSRs for five species of Marrubium [8] reported in the literature.

From the perspective of phytochemistry, members of the Marrubium genus have been found to be rich in diterpenoids, sterols, flavonoids, and phenylpropanoids, and these compounds are associated with a wide range of pharmaceutical uses such as antinociceptive, antispasmodic, antioedematogenic, antimicrobial, antiviral, and anti-inflammatory activities [9,10]. Most of these properties are reported for $M$. desertii de Noé [11], $M$. aschersonii Magnus [12-14], and mainly for M. vulgare [15-17]. The latter is considered to date as a traditional herbal medicinal product (common horehound) with long-standing use and specific indications as an expectorant in cough associated with cold, for symptomatic treatment of mild dyspeptic complaints such as bloating and flatulence, and in temporary loss of appetite [18]. Only few studies have investigated to date the chemical composition of $M$. aschersonii in secondary metabolites. The plant produces essential oil with high sesquiterpenes proportions [12]. Besides, Zhang et al. [14] and Hammami et al. [13] isolated and identified several labdane and halimane diterpenoids with anti-inflammatory activity. M. aschersonii is a perennial plant with pink bilabiate flowers and thick and whitish indumentum covering stems and leaves on both sides; it is endemic to the north, central, and south parts of Tunisia, thriving in sunny open sites of low to medium altitudes or on lowland steep slopes [19].

Despite the ethnobotanical value and medicinal uses of Marrubium members, this genus includes both commonplace species like $M$. vulgare and range-restricted ones such as the Tunisian local endemic M. ascersonii. The uncontrolled and intensive harvesting of herbal material directly from wild-growing populations that are rare, range-restricted, and confined only in small geographical territories (local endemics) may exert pressure on species survival with implications for the conservation of genetic resources [20]. In general, to assemble the necessary body of biological knowledge regarding local endemic species (such as M. ascersonii), previous studies have highlighted the importance of seed germination studies both for the in situ and the ex situ conservation of prioritized phytogenetic resources [21-25]. Taking into account the above-mentioned, great attention has been given to date to the integrated conservation of species including their sustainable exploitation in different economic sectors [24-31]. Additionally, information about 
species-specific propagation techniques is important to optimize conservation actions and restoration efforts particularly for rare, threatened, and/or local endemic species. In any case, seed propagation represents the most adequate method to maintain genetic diversity for many species or the most common and the easiest method used in nurseries [32]. Conservation-wise, applied research regarding germination, propagation, and cultivation trials needs to be species-specific to support and facilitate any conservation or sustainable exploitation strategy [25].

Regardless, the promising potential was revealed recently for $M$. aschersonii $[24,25,29]$, and the feasibility of creating value chains in different economic sectors for future sustainable exploitation was also noted [25]. The absence of relevant species-specific information renders it truly neglected and underutilized species and makes its propagation by Tunisian authorities difficult, thus hindering conservation plans or restoration programs and impeding its possible exploitation in various economic sectors. Unfortunately, $M$. aschersonii has not been researched from the perspective of its seed ecology, and consequently, questions regarding its germination requirements still remain unanswered. The knowledge of seed germination requirements of $M$. ascersonii may provide insight about the adaption of the germination process to habitat conditions and the effect of environmental factors on seed germination, thus facilitating any future conservation effort. Apart from the absence regarding seed germination data, information referring to the seedling growth and pilot cultivation of $M$. aschersonii is not available as well, thus hindering any attempt for possible sustainable exploitation. Concerning the latter perspective, apart from knowledge on species-specific propagation techniques, another main challenge is the production of quality plant stock material by specialized nurseries [25]. This is due to the harsh conditions of the Mediterranean environment (prevailing of high temperatures, low water availability, and decreased soil fertility), and therefore the quality of plant stock produced at nurseries is very important to ensure success in ex situ cultivation programs of local endemic species for conservation purposes [33]. Cultivation-wise, common nursery practice can affect the morphological and physiological characteristics of focal species as a result of the production of planting stock of improved quality aimed to increase the outplanting success [34]. Quite often the morphological and physiological attributes of planting stock are defined by the quality of the seedlings [35]. In this respect, the use of inorganic and integrated nutrient management fertilizers may considerably improve the quality of the cultivated plants $[27,31]$. Conservation-wise, habitat restoration programs usually take place on degraded or poor natural soils; hitherto, it was important to know how to adapt plant nutrient management throughout plant developmental stages and conditions in the nursery [36]. For example, it is known that applications of fertilizers in plants produced in nursery conditions usually increase the survival and growth of their seedlings when transplanted in natural wild habitat conditions [37,38].

In this context, the study herein firstly aimed to explore comparatively the potential of $M$. aschersonii in different economic sectors (ornamental-horticultural, medicinal-cosmetic, and agro-alimentary). Secondly, this study aimed to produce a detailed ecological profiling using Geographical Information Systems (GIS) providing insight on the abiotic environmental conditions that $M$. ascheronii requires in its wild habitats. This is particularly useful to understand the effect of temperature on the seed germination of M. aschersonii. Additionally, such generated knowledge represents a fundamental first step enabling both in situ conservation efforts and ex situ conservation or sustainable exploitation strategies, informing at the same time whether such conditions can be reproduced during cultivation and acclimatization in the man-made environment $[39,40]$. To further bridge extant research gaps that hinder conservation and sustainable exploitation of this promising species, the study herein moreover aimed to: (iii) Provide molecular authentication for this species, thus generating a reference genetic information of $M$. aschersonii in the GenBank allowing for genetic relatedness to other Marrubium species (molecular phylogeny) and a DNA barcoding system for $M$. aschersonii serving as a fingerprint for traceability of plant material from the wild to the field and the market and (iv) evaluate the effect of chemical 
and integrated nutrient management fertilizers on the growth of $M$. aschersonii seedlings based on measurements of morphological and physiological properties of seedlings, thus facilitating its cultivation.

\section{Materials and Methods}

\subsection{Multifaceted Evaluation in Different Economic Sectors}

Multifaceted evaluation of $M$. aschersonii in three economic sectors was conducted (Level I evaluation). More specifically, we overviewed: (i) the ornamental-horticultural potential of this plant based on twenty related attributes [25], (ii) its agro-alimentary potential based on seven related attributes, [29] and (iii) its medicinal-cosmetic potential based on nine related attributes [26]. For the multifaceted evaluation of target NUPs such as $M$. aschersonii, a new methodological scheme was created engaging a wide range of experts and experienced scientists $(n=13)$ to examine case-by-case the following: selected attributes per economic sector to be used for this kind of evaluation; the typology of evaluation attributes (sector-specific or inter-sectorial); appropriate data sources to be consulted for evaluation (one to four types per selected attribute); score scaling per attribute (two-fold to seven-fold) and directionality for the scoring of different attributes (possible scores and value definitions based on the quality and quantity of the extant information retrieved). Detailed description of this methodological scheme along with guidelines and examples of scorings of many NUPs (399 local endemic taxa of three Mediterranean regions, i.e., Crete, Mediterranean Coast-Rif of Morocco, and Tunisia) can be found in our previous studies targeted in the ornamental sector [25], the medicinal-cosmetic sector [26] and the agroalimentary sector [29]. Following the scoring of individual attributes for M. aschersonii, the sum of scorings for all attributes per economic sector was calculated and expressed as the relative percentage (\%) of the optimum possible score that could be generated in each sector $[25,26,29]$. As a result, the potential of $M$. aschersonii in different economic sectors was illustrated.

Feasibility evaluation of M. aschersonii (Level II evaluation) involved point-scoring of 12 selected attributes; these were considered either as prerequisites of common interest across various economic sectors (eight attributes) or as unique identity elements or special features (four attributes) that can be exploited in terms of product branding and marketing [25]. The designated readiness timescale evaluation for the sustainable exploitation for M. aschersonii (Level III evaluation) involved the completion of eight criteria, based on previously published Strengths, Weaknesses, Opportunities, and Threats (SWOT) and gap analyses. These evaluations were sourced from previous research [25] and are presented herein in detail for M. aschersonii.

\subsection{Distribution Mapping and GIS Ecological Profiling}

The distribution points (occurrence data) for the creation of the ecological profile of $M$. aschersonii were taken from personal database (Figure 1). Historical climate data of pixel size $30 \mathrm{~s}$ were downloaded from the website of the WorldClim (https://www. worldclim.org/data/worldclim21.html, accessed on 26 November 2021) to calculate for the species' distribution points the minimum, maximum, and average temperatures and mean values of 19 bioclimatic variables, i.e., Annual Mean Temperature (Bio_1), Mean Diurnal Range (Bio_2), Isothermality (Bio_3), Temperature Seasonality (Bio_4), Max Temperature of Warmest Month (Bio_5), Min Temperature of Coldest Month (Bio_6), Temperature Annual Range (Bio_7), Mean Temperature of Wettest Quarter (Bio_8), Mean Temperature of Driest Quarter (Bio_9), Mean Temperature of Warmest Quarter (Bio_10), Mean Temperature of Coldest Quarter (Bio_11), Annual Precipitation (Bio_12), Precipitation of Wettest Month (Bio_13), Precipitation of Driest Month (Bio_14), Precipitation Seasonality (Bio_15), Precipitation of Wettest Quarter (Bio_16), Precipitation of Driest Quarter (Bio_17), Precipitation of Warmest Quarter (Bio_18), and Precipitation of Coldest Quarter (Bio_19). To create the ecological profile of $M$. aschersonii in the GIS-application, the following layers were used: 
(a) WorldClim version 2.1, containing minimum, maximum, and average temperatures $\left({ }^{\circ} \mathrm{C}\right)$ as well as precipitation values $(\mathrm{mm})$ and data for 19 bioclimatic variables for every month derived from 1970-2000, with a raster resolution of $1 \mathrm{~km}^{2}$, and

(b) Marrubium aschersonii distribution points raster file (Figure 1).

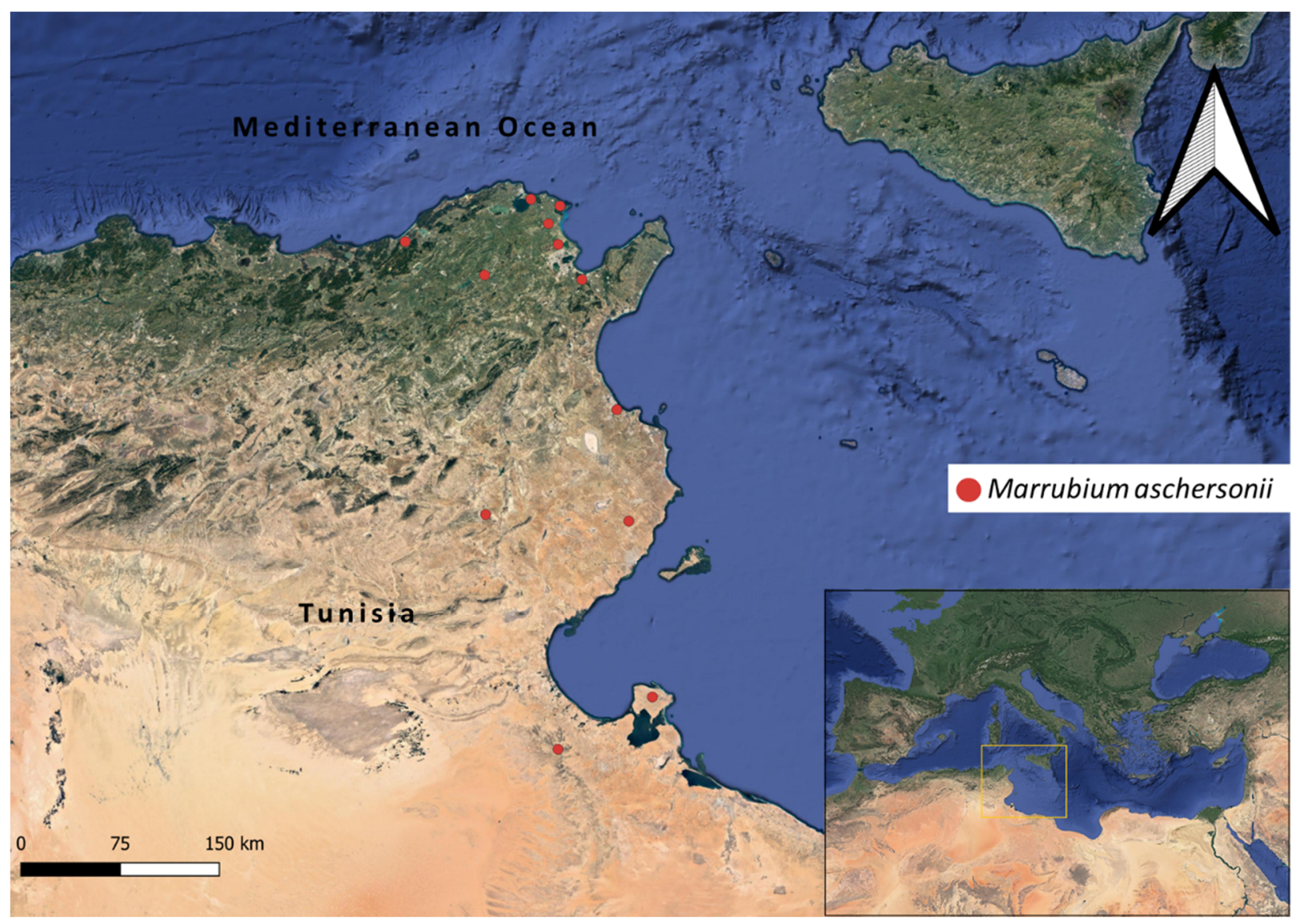

Figure 1. Known occurrences (distribution points with red color) of the local endemic Marrubium aschersonii (Lamiaceae) in Tunisia (between Ain Ouled Sebaa and Tabarka; Menzel Djemil; HammamLif; Sousse; Sfax; Sidi Bou Zid; Djerba; Matmata; National Park d'Ichkeul; Medjez el Beb; Zembra; Borj Touil, north of Tunis; Ghar el Melh; Chaouach, north of Toukaber-Medjez el Bab).

\subsection{Seed Collection and Storage}

M. aschersonii inflorescences were collected on 18 June 2019 by hand from many wildgrowing individuals in sparsely vegetated shrub land close to Chaouch village, northern Tunisia (Figure 2) at $30 \mathrm{~m}$ above sea level (09.540415 N, 36.711894 E). The plants from which seeds were harvested were taxonomically identified using the standard floras of Tunisia [41,42]. Among five native Marrubium taxa in Tunisia, M. aschersonii differs from other taxa of this genus essentially by the number of calyx teeth (10 teeth for $M$. vulgare, 6-8 unequal teeth for M. aschersonii, and 5 for M. supinum, M. desesrtii, and M. alysson) [42]. 


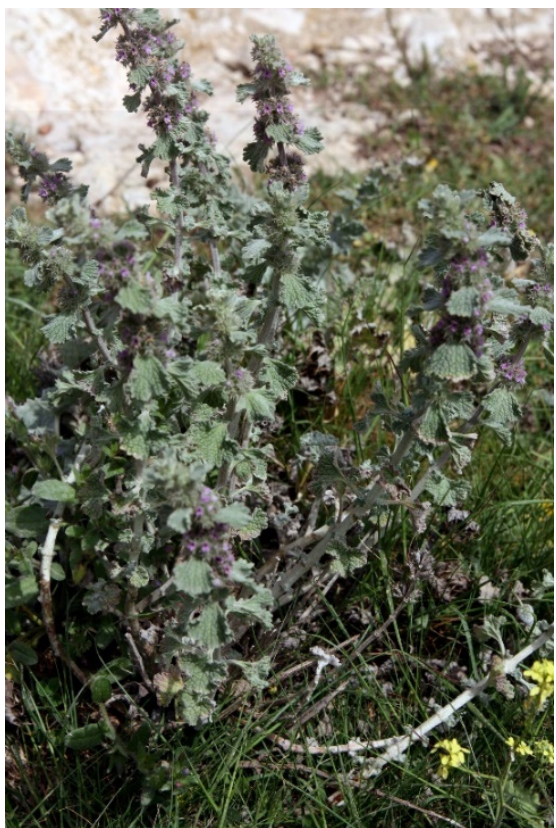

(A)

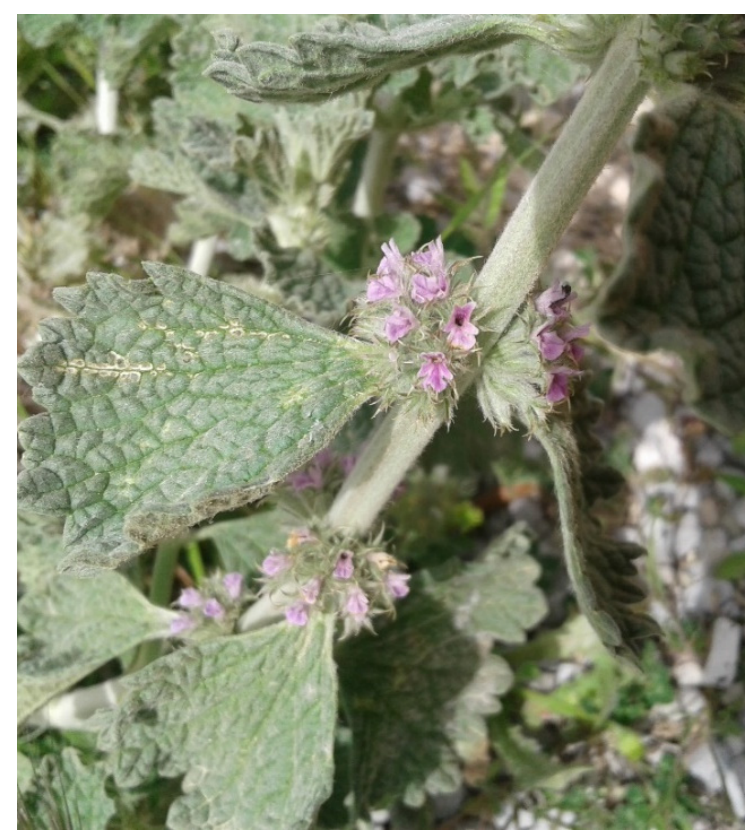

(B)

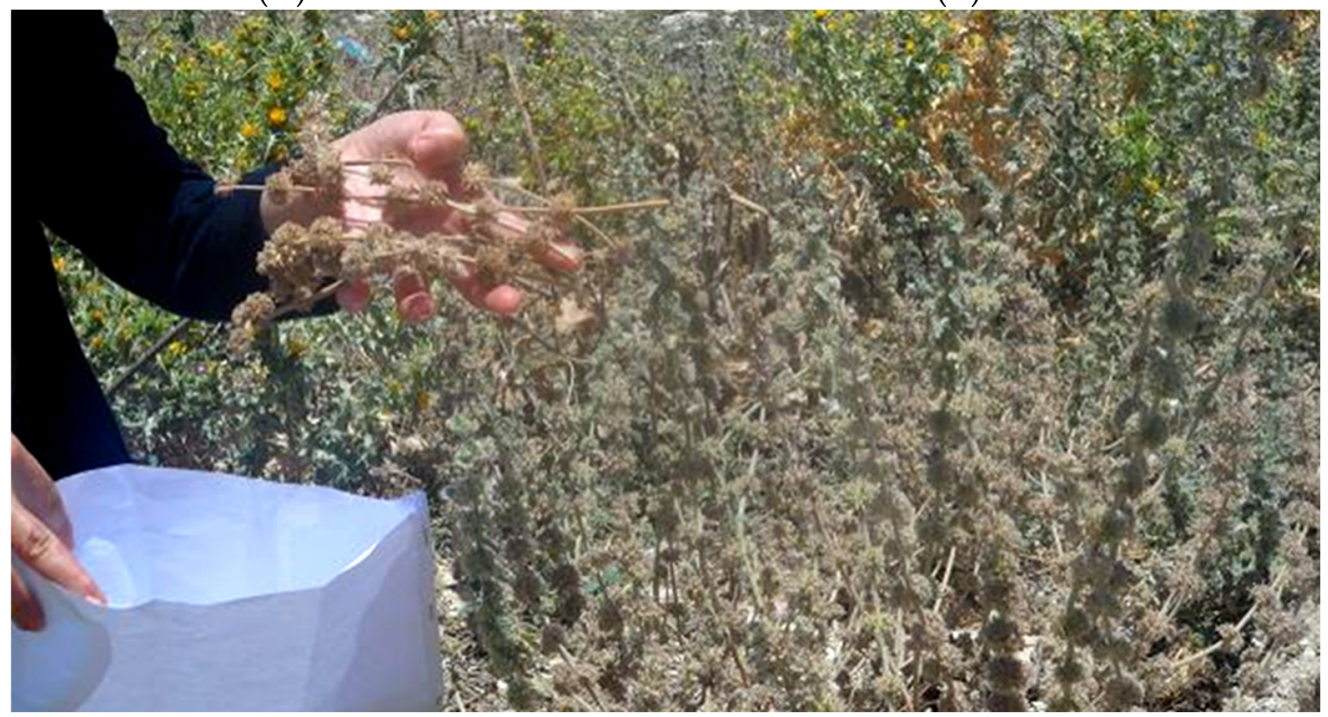

(C)
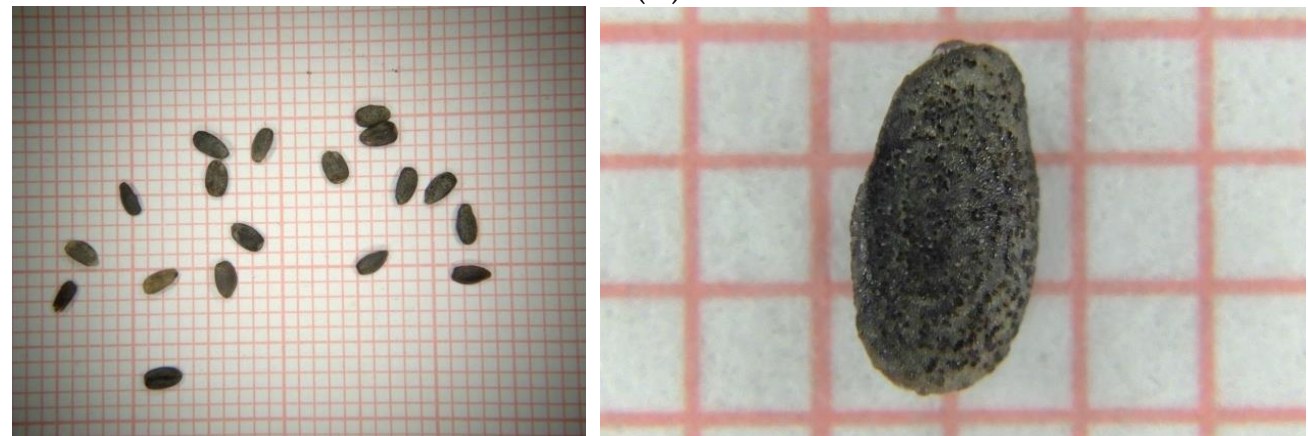

(D)

Figure 2. Wild-growing individual of Marrubium aschersonii in its natural habitat (A) close to Chaouch village, Tunisia with verticillasters of bilabitae pink flowers and hairy leaves in spring (B) (Photos: Gisèle Dahlia, reproduced with permission), dried inflorescences in summer (C), extracted seeds and exterior seed morphology (D). 
After harvesting, the inflorescences were spread out on filter papers in laboratory conditions for 15 days and were left to dry naturally. Individual seeds were extracted by hand-rubbing the calyces, and, subsequently, the seeds and debris were carefully separated by sieving and flowing. The cleaned seeds were transfer at the Seed Bank of the Institute of Plant Breeding and Genetic Resources, Agricultural Organization Demeter in Thessaloniki, Greece, where the seeds were taxonomically verified based on their morphological features [41,42] and were assigned with an International Plant Exchange Network (IPEN) accession number TN-1-BBGK-20,116. The cleaned seedlot of $M$. aschersonii was stored in glass containers in the seed bank $\left(3-5^{\circ} \mathrm{C}\right)$ until used in the germination experiments.

\subsection{Germination Test}

Germination experiments were started the following December and were conducted in the laboratory of Floriculture, School of Agriculture, Aristotle University of Thessaloniki. Seeds of M. aschersonii were placed in growth chambers (CRW-500SD Chrisagis, Athens, Greece) to evaluate the germination response at four constant temperature regimes (10, 15,20 , and $25^{\circ} \mathrm{C}$ ) with four replications of 20 seeds for each temperature treatment. The seeds were placed on filter paper moistened with distilled water in $9 \mathrm{~cm}$ sterile plastic Petri dishes, which were randomly arranged on the shelves of the growth chambers, under a $12 \mathrm{~h}$ light/12-dark photoperiod; filter paper was kept moist by adding distilled water when required throughout the experimental period. Germinated seeds were counted every five days for a period of 45 days, and thereafter they were removed from the Petri dishes. A seed was considered as germinated when the radicle was emerged from the seed coat.

\subsection{Molecular Markers and PCR Procedures}

Plant material was collected from greenhouse-grown plants of $M$. aschersonii, which were derived from the seed germination trials. Genomic DNA was extracted from $\pm 250 \mathrm{mg}$ of young leaves of $M$. aschersonii according to a modified CTAB protocol [43]. The quality of DNA was checked on a $1 \%$ agarose gel, and the concentration was measured by spectrophotometer (NanoDrop ${ }^{\mathrm{TM}}$ One, Thermo Fisher Scientific, Cincinnati, OH, USA). DNA templates were PCR amplified using oligonucleotide primers (VBC-BIOTECH GmbH, Wien, Austria) for 18S-26S (458 bp), matK (858 bp), petB/petD (1002 bp), rbcL (656 bp), rpoC1 (504 bp), trnH/psbA (365 bp), and trnL/trnF (877 bp) molecular markers. The PCR procedure, sequences of the oligonucleotide primers, reagents, sequencing of PCR products, and analysis of DNA sequences followed the methodology and the use of technical tools described by [44]. BLAST searches were applied to all produced sequences using the available online databases (DDBJ/EMBL/GenBank). New sequence information of M. aschersonii was deposited in GenBank obtaining specific accession numbers OM212033-OM212038 and OM250036 for each of the above molecular markers. The pairwise genetic distance and the neighbor-joining tree were constructed using the Molecular Evolutionary Genetics Analysis (MEGA) 11.0 program [45,46].

\subsection{Pilot Cultivation of Seedlings, Transplanting, and Fertilization Treatments}

In the second phase, the germinated seeds from the germination experiment of the study species were placed in $6 \times 6 \times 6.5 \mathrm{~cm}$ containers plastic pots filled with a 3:1 $(v / v)$ mixture of enriched peat (TS1, Klasmann-Deilmann, Geeste, Germany) and perlite (Isocon, Athens, Greece). The germinated seeds were carefully covered with sand, and the container pots were randomly placed on a bench in the greenhouse. Watering was applied to maintain the proper moisture conditions for further growth.

The seedlings were grown in the container pots until their root system was welldeveloped. In the middle of March, the seedlings were carefully transplanted into final containers (new plastic pots) with dimensions of $9.5 \times 9.5 \times 10.5 \mathrm{~cm}$. The final containers were filled with a mixture with soil, enriched peat (TS2, Klasmann-Deilmann, Geeste, Germany), and perlite (Isocon, Athens, Greece) that was prepared in a ratio of 4:5:1 (v/v). The above ratio was selected after preliminary experiments (data not shown). In order to 
estimate the soil fertility, before the preparation of the substrate, a sample of approximately $1.5 \mathrm{~kg}$ soil was taken and transferred to the laboratory for chemical analyses. The results of chemical analyses showed that the soil used was moderately coarse in texture with an alkaline reaction $(\mathrm{pH})$, a high content of calcium carbonate, low organic matter, and normal salinity (Table 1).

Table 1. Chemical and physical properties of the soil used in experimentation.

\begin{tabular}{|c|c|c|c|c|c|c|}
\hline \multirow{2}{*}{$\mathrm{pH}$} & \multirow{2}{*}{ Organic Matter (\%) } & \multirow{2}{*}{ Soluble Salts $(\mathrm{mS} / \mathrm{cm})$} & \multirow{2}{*}{$\mathrm{CaCO}_{3}(\%)$} & \multicolumn{3}{|c|}{ Mechanical Composition } \\
\hline & & & & Sand $(\%)$ & Silt (\%) & Clay $(\%)$ \\
\hline \multirow[t]{7}{*}{8.12} & 0.36 & 0.35 & 5.50 & 56.00 & 28.00 & 16.00 \\
\hline & \multicolumn{6}{|c|}{ Macronutrient concentrations (ppm) } \\
\hline & $\mathrm{N}-\mathrm{No}_{3}$ & $\mathrm{P}$ & $\mathrm{K}$ & $\mathrm{Mg}$ & $\mathrm{Ca}$ & \\
\hline & 8.00 & 8.00 & 104.00 & 842.00 & $>2000$ & \\
\hline & \multicolumn{6}{|c|}{ Micronutrient concentrations (ppm) } \\
\hline & $\mathrm{Fe}$ & $\mathrm{Zn}$ & $\mathrm{Mn}$ & $\mathrm{Cu}$ & & \\
\hline & 4.7 & 2.00 & 7.06 & 0.77 & & \\
\hline
\end{tabular}

After seedling transplanting, the pots were randomly divided into three groups. In each group, there were eight replicates. In the seedlings of the first group of pots, a conventional (chemical) fertilization mixture $(\mathrm{ChF})$ was applied, and in those of the second group of pots, special integrated nutrient management (INM) fertilization was appliedwhereas in the seedlings of the last group of pots, no fertilization was applied (control). Both types of fertilizers were applied through foliar spray application. The INM fertilization by foliar application consisted of nutrient solution with THEORUN at $7 \mathrm{~mL} / \mathrm{L}$, THEOCAL at $1.5 \mathrm{~g} / \mathrm{L}$, THEOFAST at $5 \mathrm{~mL} / \mathrm{L}, 10-47-10$ (AGRI.FE.M. LTD Fertilizers, Korinthos, Greece) at $3.2 \mathrm{~g} / \mathrm{L}, \mathrm{K}_{2} \mathrm{SO}_{4}$ (0-0-52, AGRI.FE.M. LTD Fertilizers, Aspropirgos, Greece) at $2.07 \mathrm{~g} / \mathrm{L}$,

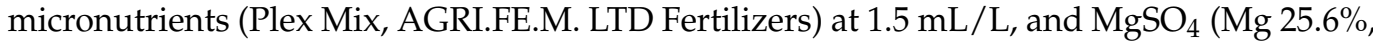
AGRI.FE.M. LTD Fertilizers) at $0.6 \mathrm{~g} / \mathrm{L}[27,31]$. The conventional fertilization by foliar application used a nutrient solution that consisted of $\mathrm{NH}_{4} \mathrm{NO}_{3}\left(34,4-0-0\right.$, Neofert ${ }^{\circledR}$, Neochim PLC, Dimitrovgrad, Bulgaria) at $2.7 \mathrm{~g} / \mathrm{L}, \mathrm{Ca}\left(\mathrm{NO}_{3}\right)_{2}$ (NITROCAL, Agrohimiki, Greece) at $1.7 \mathrm{~g} / \mathrm{L}, 10-47-10$ at $3.2 \mathrm{~g} / \mathrm{L}, \mathrm{K}_{2} \mathrm{SO}_{4}(0-0-52)$ at $2.27 \mathrm{~g} / \mathrm{L}$, micronutrients Plex Mix at $1.5 \mathrm{~mL} / \mathrm{L}$, and $\mathrm{MgSO}_{4}(\mathrm{Mg} 25.6 \%)$ at $0.6 \mathrm{~g} / \mathrm{L}[27,31]$. The fertilization started at the end of March and was completed at the middle of June. Twelve weekly applications were performed with complete wetting of the leaf until the fertilizer solution was drained. The plants were grown inside a glasshouse of the laboratory of Floriculture, School of Agriculture, in the farm of Aristotle University of Thessaloniki. During the experimental period, the plants were irrigated every three days until the substrate was moist.

\subsection{Morphological and Physiological Measurements of Seedlings}

At the end of June, the effect of the fertilization treatment was evaluated based on selected morphological variables. The main shoot height $(\mathrm{SH})$ and root collar diameter (RCD) of all plants and treatment were measured. The SH and RCD were measured using a metal ruler and a digital caliper, respectively. In addition, the number and the dimensions (length and width) of 10 leaves from each plant per treatment were measured. Subsequently, four plants per treatment were randomly sampled for the measurement of the root dry biomass (RDB) and the aboveground part dry biomass (AGDB) and for the determination of the tissue nutrient concentration. Dry weights of plants were determined after drying in an oven at $74{ }^{\circ} \mathrm{C}$ for $48 \mathrm{~h}$.

At the same time, gas-exchange parameters, chlorophyll, and chlorophyll fluorescence were determined. The photosynthetic rate $\left(\mu \mathrm{mol} \mathrm{m} \mathrm{m}^{-2} \mathrm{~s}^{-1}\right)$ was measured by using the portable gas-exchange system LCi ADC Gas Analyzer (ADC BioScientific Ltd., Hoddesdon, UK). Counting from the stem top, the 3rd or 4th younger and fully expanded leaf was clipped by the chamber with a window area of $6.25 \mathrm{~cm}^{2}$. Measurements were taken on sunny days between 10:00 a.m. and 2:00 a.m. with the ambient temperature ranging from 
$25.1^{\circ} \mathrm{C}$ to $29.8^{\circ} \mathrm{C}$ and the leaf chamber temperature from $25.3^{\circ} \mathrm{C}$ to $30.9{ }^{\circ} \mathrm{C}$, while the ambient $\mathrm{CO}_{2}$ concentration (Cref) was $317.56 \mu \mathrm{mol} \mathrm{mol}^{-1}$, and the range of the chamber's water-vapor pressure was 6-8 $\mathrm{m}$ bar.

For the chlorophyll measurements, a chlorophyll meter CCM 200 (Opti-sciences, Tyngsboro, MO, USA) was used for calculating the chlorophyll content index (CCI) based on the ratio of transmittance measurement at 660 and $940 \mathrm{~nm}$ [47].

The chlorophyll-fluorescence parameter $\mathrm{F}_{\mathrm{v}} / \mathrm{F}_{\mathrm{m}}$ was measured by a OS30p+ Rapid Plant Stress Screening Device (Opti-sciences, Tyngsboro, MO, USA). Fv/Fm is the ratio of variable $(\mathrm{v})$ to maximum $(\mathrm{m})$ fluorescence after dark-adaptation, representing the maximum photochemical efficiency of photosystem II, which is used to detect various stress conditions [48].

Twelve measurements with CCM200 and OS30p+ were taken on six fully expanded young leaves of $M$. aschersonii individuals from the middle of the branches in each treatment.

\subsection{Plant Tissue Analyses of Seedlings}

Plant tissues of the dried aboveground part were finely grounded to pass a 40-mesh sieve. Specifically, for the determination of tissue nutrient concentration, only the leaves of four dry aboveground parts per treatment were grounded. There were three samples of fine powder, which corresponded to the three fertilization treatments applied to plants (ChF, INM, and control). From each sample, three subsamples of ca. $0.25 \mathrm{~g}$ each were taken (thus, the total number of subsamples was 18). Each subsample was disorganized by the method of wet oxidation using a triple-acid mixture of $\mathrm{H}_{2} \mathrm{SO}_{4}, \mathrm{HNO}_{3}$, and $\mathrm{HClO}_{4}$ in a ratio of 5:1:1 at $80^{\circ} \mathrm{C}$ until a transparent solution was obtained [49]. The digested samples were filtered using Whatman No. 42 filter papers, and the filtrates were finally complemented with distilled water up to $50 \mathrm{~mL}$. The solutions were analyzed for total phosphorus $(\mathrm{P})$ colorimetrically according to the Molybdenum Blue method by using a Shimadzu spectrophotometer model UV-1201V [50]. The total concentrations of magnesium $(\mathrm{Mg})$, potassium $(\mathrm{K})$, calcium $(\mathrm{Ca})$, copper $(\mathrm{Cu})$, iron $(\mathrm{Fe})$, zinc $(\mathrm{Zn})$, and manganese (Mn) were determined by atomic absorption spectroscopy (Perkin-Elmer AAnalyst 300). Acetylene gas was used as fuel and air as a supportive agent. An oxidizing flame was used in all cases. Furthermore, for the determination of nitrogen $(N)$, three subsamples of the powder (each ca. $0.25 \mathrm{~g}$ ) were taken from each sample. Total $N$ was determined by the Kjeldahl method [51].

Leaf Nutrient Analyses were conducted in the Laboratory of Forest Soil Science, School of Forestry, and Natural Environment, Aristotle University of Thessaloniki, Greece.

\subsection{Statistical Analysis}

The experimental design was a completely randomized design. The data were subjected to analysis of variance (one-way ANOVA), and the comparisons of the means were estimated using the Duncan's test at significance level $p \leq 0.05$ [52]. Prior to the ANOVA, only the germination percentage data were transformed to arc-sine square root values [53]. All statistical analyses were carried out using SPSS 21.0 (SPSS, Inc., Armonk, NY, USA).

\section{Results}

\subsection{Overview of the Potential of Marrubium aschersonii in Economic Sectors}

Among the 82 Tunisian local endemics comparatively examined in terms of ornamentalhorticultural potential [25], Marrubium aschersonii showed a 34.17\% overall score (Figure 3A), showing rather an interesting general potential in the ornamental-horticultural sector compared to the highest-evaluated Tunisian endemic species, namely, Limonium byzacium Brullo and Erbern (47.5\%). Regarding different subsectors of the ornamental-horticultural industry, M. aschersonii has above-average promising potential as a pot/patio plant with $57.29 \%$ of the optimum possible score, ranking it among the top-three Tunisian local endemics; otherwise, it may be possibly eligible for landscaping and xeroscaping applications (45.70\% and $42.49 \%$ of the possible optimum score, respectively) [25]. 


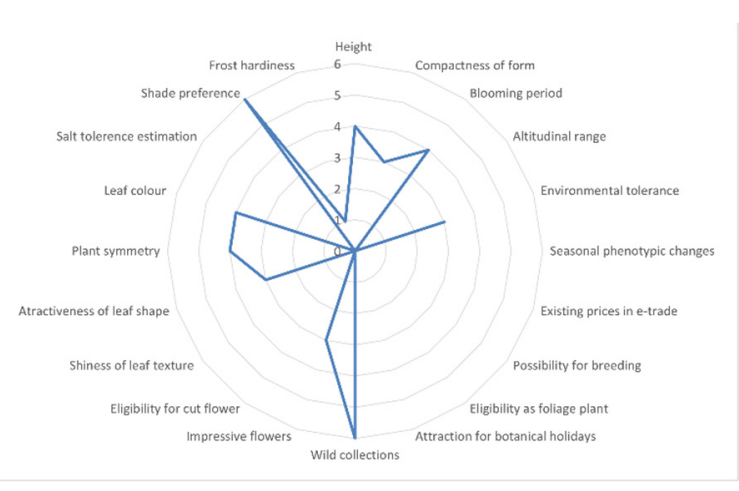

(A)

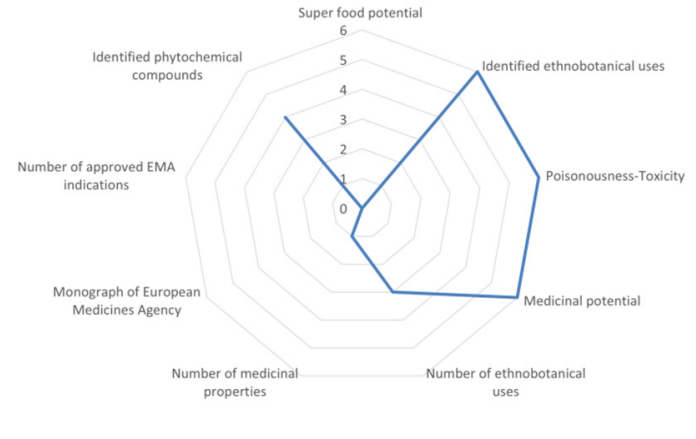

(B)

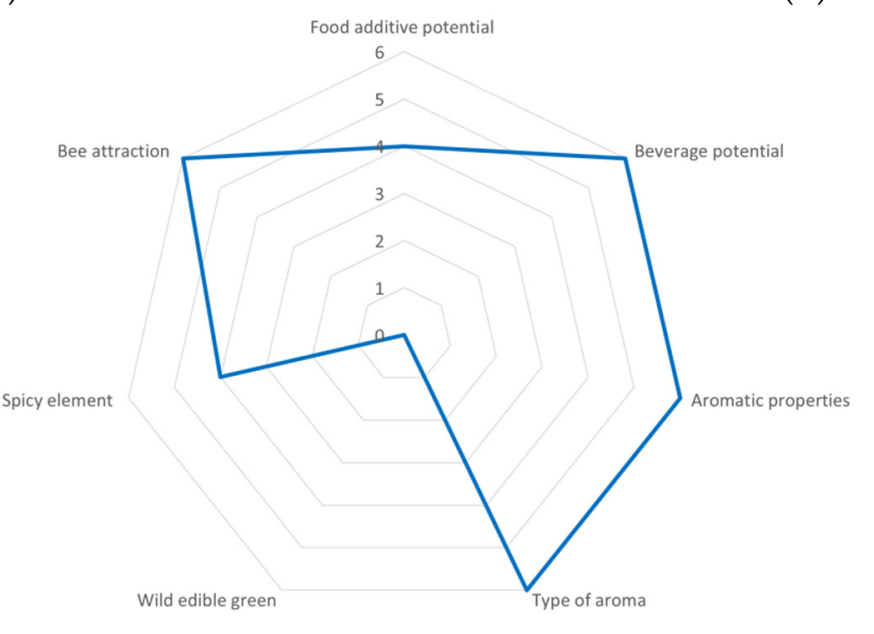

(C)

Figure 3. Multifaceted evaluation of Marrubium aschersonii in different economic sectors with scores for: (A) 20 ornamental-horticultural attributes resulting in $34.17 \%$ of the optimum possible score (hierarchically ranked in the lowest $>35 \%$ class, Krigas et al. [25]); (B) nine medicinal-cosmetic attributes; and (C) seven agro-alimentary attributes reaching $48.15 \%$ and $76.19 \%$ of the optimum possible scores, respectively (these scores hierarchically ranked M. ascersonii in lower to average and highest classes, respectively—see Libiad et al. [54] and Bourgou et al. [26], respectively).

M. aschersonii scored $48.15 \%$ in the medicinal-cosmetic sector (Figure 3B) and was included among the top cases of local Tunisian plants with interesting medicinal-cosmetic potential mainly due to its identified ethnobotanical uses and medicinal properties [26].

M. aschersonii scored $76.19 \%$ in the agro-alimentary sector (Figure 3C), and it was the highest evaluated taxon among the 82 local Tunisian endemics examined [29], showing a very interesting potential based on ethnobotanical evidence.

Nevertheless, in terms of feasibility for sustainable exploitation (Level II evaluation, Krigas et al. [25]) M. aschersonii received a low score (26.39\%) compared to other local endemic plants of Tunisia, which hierarchically ranked this taxon in the lowest class. This fact outlines important gaps associated with its possible sustainable exploitation. In this way, the readiness timescale for value-chain creation regarding $M$. aschersonii (Level III evaluation upon completion of eight criteria) was assessed as achievable but with an indeterminable horizon [25].

\subsection{Molecular Characterization of M. aschersonii and Annotation in GenBank}

Seven different molecular markers were evaluated in M. aschersonii, and its DNA sequences were analyzed and deposited in the GenBank database. Since there were no previous DNA sequence submissions in GenBank for M. aschersonii, these data provide first-time valuable information for DNA comparisons with other Marrubium species. These 
molecular markers were selected according to previous studies and single loci proposed by the Consortium for the Barcode of Life (CBOL Plant Working Group1) [55].

Annotation of the DNA sequences of $M$. aschersonii in the GenBank for the maturase (matK) gene was matched with nine Marrubium accessions (Table 2), which are genetically verified to $2 \mathrm{bp}$ with $M$. alysson, to $4 \mathrm{bp}$ with $M$. crassidens Boiss., to $9 \mathrm{bp}$ with $M$. peregrinum L., to $9 \mathrm{bp}$ with $M$. thessalum Boiss and Heldr, and to 9-12 bp with five isolates of $M$. vulgare. The annotated ribulose 1,5-bisphosphate carboxylase/oxygenase $(r b c \mathrm{~L})$ gene of M. aschersonii was matched to 14 Marrubium accessions (Table 1), which differed to $5 \mathrm{bp}$ with $M$. incanum Desr., to $5 \mathrm{bp}$ with $M$. peregrinum, and to 6-18 bp for twelve isolates of M. vulgare. The locus of intergenic spacer between $\mathrm{tRNA}-\mathrm{His}(\operatorname{trn} \mathrm{H})$ and photosystem II protein D1 (psbA) gene of M. aschersonii was matched to five Marrubium accessions (Table 2), which varied to $7 \mathrm{bp}$ with $M$. peregrinum, $3 \mathrm{bp}$ and a $25 \mathrm{bp}$ deletion with $M$. crassidens, and 7 and $12 \mathrm{bp}$ with two isolates of $M$. vulgare; however, there was one more accession of $M$. vulgare (HM590121) recorded in the database with unreliable matching to any Marrubium trn $\mathrm{H} / p s b \mathrm{~A}$ DNA sequences. The external transcribed spacer between the $18 \mathrm{~S}$ and $26 \mathrm{~S}$ ribosomal RNA genes of $M$. aschersonii was annotated and did not match to any Marrubium DNA sequences (Table 2), although there were two DNA sequences of $M$. crassidens and M. supinum L. in the database; however, Ballota nigra L. (MK909579) was the closest match to $M$. aschersonii with $87 \%$ similarity. The locus between the cytochrome b6 (petB) and cytochrome b6/f complex subunit IV (petD) genes (petB/petD molecular marker) and the RNA polymerase beta' subunit (rpoC1) gene DNA sequences of $M$. aschersonii found no matches (Table 2) and therefore provide new DNA sequence data in GenBank for any member of the genus Marrubium. Lastly, the locus of intergenic spacer between the tRNA-Leu (trnL) and the tRNA-Phe $(\operatorname{trnF})$ genes of M. aschersonii was matched to 25 different Marrubium species, and hence a phylogenetic dendrogram was constructed to identify the genetic distance among different Marrubium species (Figure 4).

\subsection{Ecological Profiling of Marrubium aschersonii}

Based on the natural distribution range of M. aschersonii, a GIS ecological profile was generated depicting the abiotic conditions of its wild habitats in terms of temperature and precipitation (Figure 5).

Temperature-related attributes: According to historical climate data associated with the wild habitats of $M$. ascersonii (Figure 5), the lowest mean average temperature has been recorded in mid and late winter, i.e., January $\left(10.80 \pm 0.92{ }^{\circ} \mathrm{C}\right)$ and February $\left(11.45 \pm 1.02{ }^{\circ} \mathrm{C}\right)$. During the spring months, the average temperature usually begins to rise gradually from $13.24 \pm 1.21{ }^{\circ} \mathrm{C}$ in March to $23.69 \pm 1.46^{\circ} \mathrm{C}$ in June until the mid and late summer months, and the highest average temperatures usually occur in July $\left(26.56 \pm 1.50{ }^{\circ} \mathrm{C}\right)$ and August $\left(27.02 \pm 1.13^{\circ} \mathrm{C}\right)$. Later, the average temperature starts decreasing gradually from $24.33 \pm 1.16{ }^{\circ} \mathrm{C}$ in September to $20.27 \pm 1.13{ }^{\circ} \mathrm{C}$ in October, reaching colder temperatures in November $\left(15.42 \pm 1.02{ }^{\circ} \mathrm{C}\right)$ and December $\left(12.03 \pm 0.95^{\circ} \mathrm{C}\right)$. Within this seasonal pattern, the minima of mean temperatures can be as low as $4.30{ }^{\circ} \mathrm{C}$ in January, and the maxima of mean temperatures can be as high as $38.30{ }^{\circ} \mathrm{C}$ in July (Figure 5). The latter data in combination with the mean diurnal range $\left(10.38 \pm 1.13^{\circ} \mathrm{C}\right)$ as well as with the annual mean temperature $\left(18.34 \pm 1.06^{\circ} \mathrm{C}\right)$ indicate that $M$. aschersonii grows and thrives in a favorable environment without experiencing temperature extremes. This is also confirmed by the minimum mean temperature, which historically has not been reported to drop down below $0{ }^{\circ} \mathrm{C}\left(\mathrm{T}_{\min }\right.$ of $\mathrm{T}_{\min }=4.30{ }^{\circ} \mathrm{C}$ in January) during the lowest average temperature month (January). In addition, the maximum mean temperature has not been reported to rise up above $40{ }^{\circ} \mathrm{C}\left(\mathrm{T}_{\text {mean }}\right.$ of $\mathrm{T}_{\max }=38.30^{\circ} \mathrm{C}$ in July). In fact, the $\mathrm{T}_{\min }$ of $\mathrm{T}_{\text {min }}$ in January shows that $M$. aschersonii is wild-growing in sites where the winter season is rather mild. These values may indicate the natural hardiness of this species in terms of temperature extremes. 
Table 2. Nucleotide analysis and comparison of Marrubium aschersonii with other Marrubium species based on six studied molecular markers. Numbers indicate nucleotide differences (including gaps) compared to $M$. aschersonii; multiple numbers in columns show differences between different accessions deposited in the GenBank.

\begin{tabular}{|c|c|c|c|c|c|c|}
\hline Marrubium Species & matK & $r b c L$ & $\operatorname{trnH} / p s b A$ & $18 S-26 S$ & petB/petD & rpoC1 \\
\hline M. vulgare & $\begin{array}{c}9,9,9,9 \text {, and } 12 \\
\text { (5 accessions) }\end{array}$ & $\begin{array}{c}6,6,18,18, \text { and } 8 \times 7 \\
\text { bp (12 accessions) }\end{array}$ & 7,12 & - & - & - \\
\hline M. crassidens & 4 & & $\begin{array}{c}3 \text { and a } \\
\text { deletion of } 25\end{array}$ & - & - & - \\
\hline M. incanum & & 5 & & - & - & - \\
\hline M. peregrinum & 9 & 5 & 7 & - & - & - \\
\hline M. alysson & 2 & & & - & - & - \\
\hline M. thessalum & 9 & & & - & - & - \\
\hline
\end{tabular}

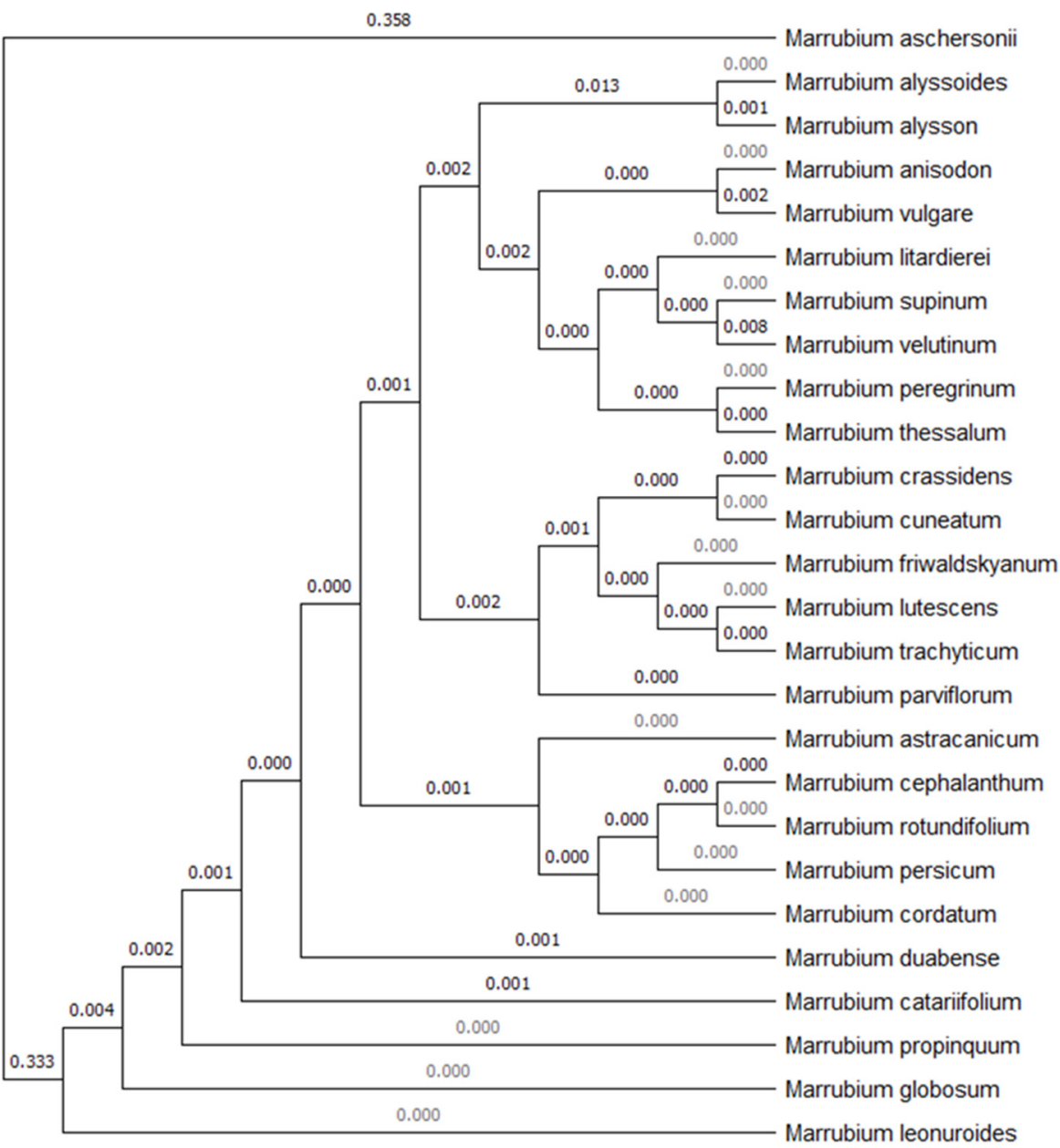

Figure 4. Phylogenetic tree of Marrubium species and pairwise genetic distances including the studied M. aschersonii based on the $t r n \mathrm{~L} / \operatorname{trn} \mathrm{F}$ molecular marker sequence using the neighbor-joining method. 


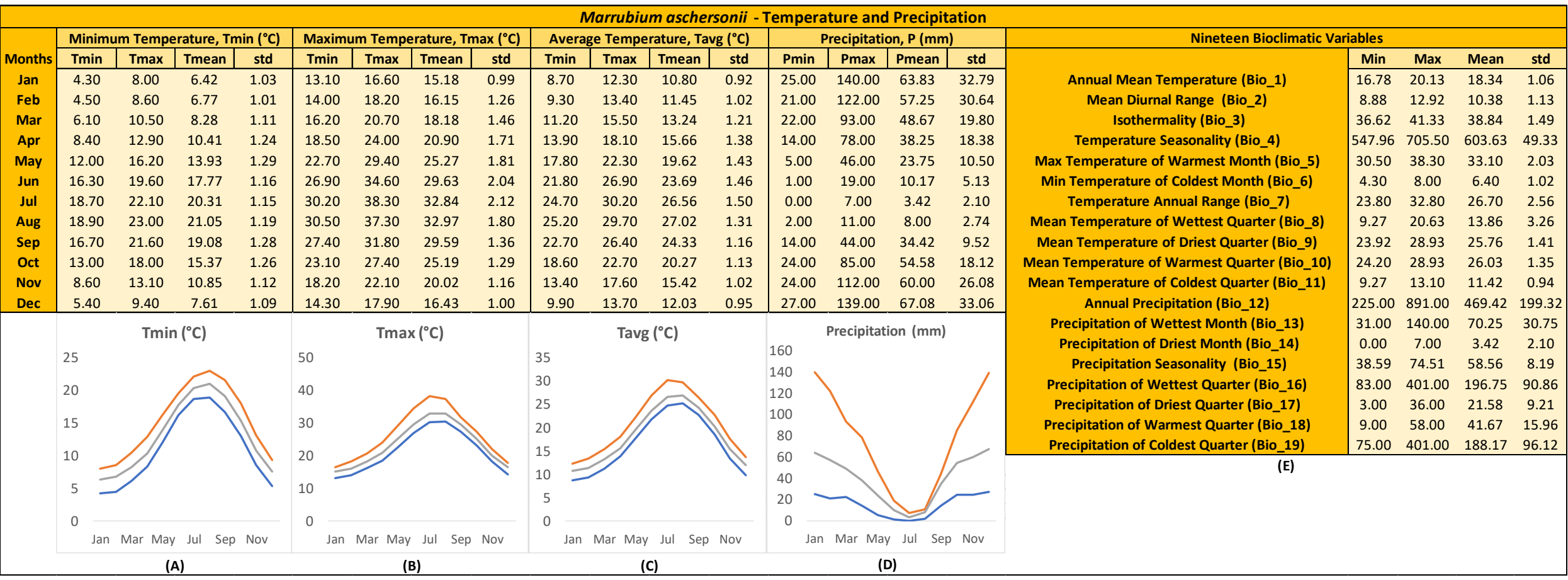

Figure 5. GIS-derived ecological profile across the natural distribution range of Marrubium aschersonii wild-growing populations in Tunisia (Figure 1) with prevailing (A) minimum temperatures per month $\left({ }^{\circ} \mathrm{C}\right),(\mathbf{B})$ maximum temperatures per month $\left({ }^{\circ} \mathrm{C}\right),(\mathbf{C})$ average temperatures per month $\left({ }^{\circ} \mathrm{C}\right),(\mathbf{D})$ precipitation per month $(\mathrm{mm})$, and (E) values for 19 bioclimatic variables extracted from WorldClim version 2.1. In each case, minimums, maximums, averages, and standard deviations are shown. Line graphs illustrate the minimum (blue lines), maximum (orange lines), and mean (grey lines) monthly values for temperature $\left({ }^{\circ} \mathrm{C}\right)$ and precipitation $(\mathrm{mm})$. 
Precipitation-related attributes: Based on M. aschersonii occurrence points, precipitation data in its wild habitats suggest a strong seasonality (Figure 5). Historically, the rainiest months in the species' natural range are December and January with $67.08 \pm 33.06 \mathrm{~mm}$ and $63.83 \pm 32.79 \mathrm{~mm}$, respectively. From February $(57.25 \pm 30.64 \mathrm{~mm})$ to May $(23.75 \pm 10.50 \mathrm{~mm})$, precipitation has been shown to decrease, leading to the dry summer season, with July $(3.42 \pm 2.10 \mathrm{~mm})$ being the driest month. From July onwards, precipitation is reported as slightly increasing in August $(8.00 \pm 2.74 \mathrm{~mm})$ and markedly so during the autumn months, i.e., September (34.42 $\pm 9.52 \mathrm{~mm})$, October $(54.58 \pm 18.12 \mathrm{~mm})$, and November $(60.00 \pm 26.08 \mathrm{~mm})$. It is noteworthy that throughout the wet autumn and winter months, precipitation may vary considerably, e.g., from $P_{\text {mean }}=67.08 \pm 33.06 \mathrm{~mm}$ toe $P_{\max }=139.00 \mathrm{~mm}$ in December, thus suggesting that from year to year the total precipitation in the wild habitats of $M$. aschersonii can be quite different.

\subsection{Seed Germination Tests}

The germination percentages of $M$. aschersonii were affected significantly by temperature (Figure 6). The seeds incubated at 15 and $20{ }^{\circ} \mathrm{C}$ exhibited the highest germination percentage $\left(68.75 \%\right.$ and $60 \%$, respectively). Although the seeds incubated at $15^{\circ} \mathrm{C}$ started germinating about five days later compared with the seeds incubated at $20{ }^{\circ} \mathrm{C}$, in both temperatures the germination was completed on the 20th day from the beginning of the test (Figure 6). The increase in incubation temperature to $25^{\circ} \mathrm{C}$ resulted in a significant drop of the number of germinated seeds (45\%) of $M$. aschersonii. However, seed germination was faster at the higher temperatures $\left(20\right.$ and $\left.25^{\circ} \mathrm{C}\right)$, while seeds incubated at $10{ }^{\circ} \mathrm{C}$ exhibited the lowest germination percentage $(28.75 \%)$.

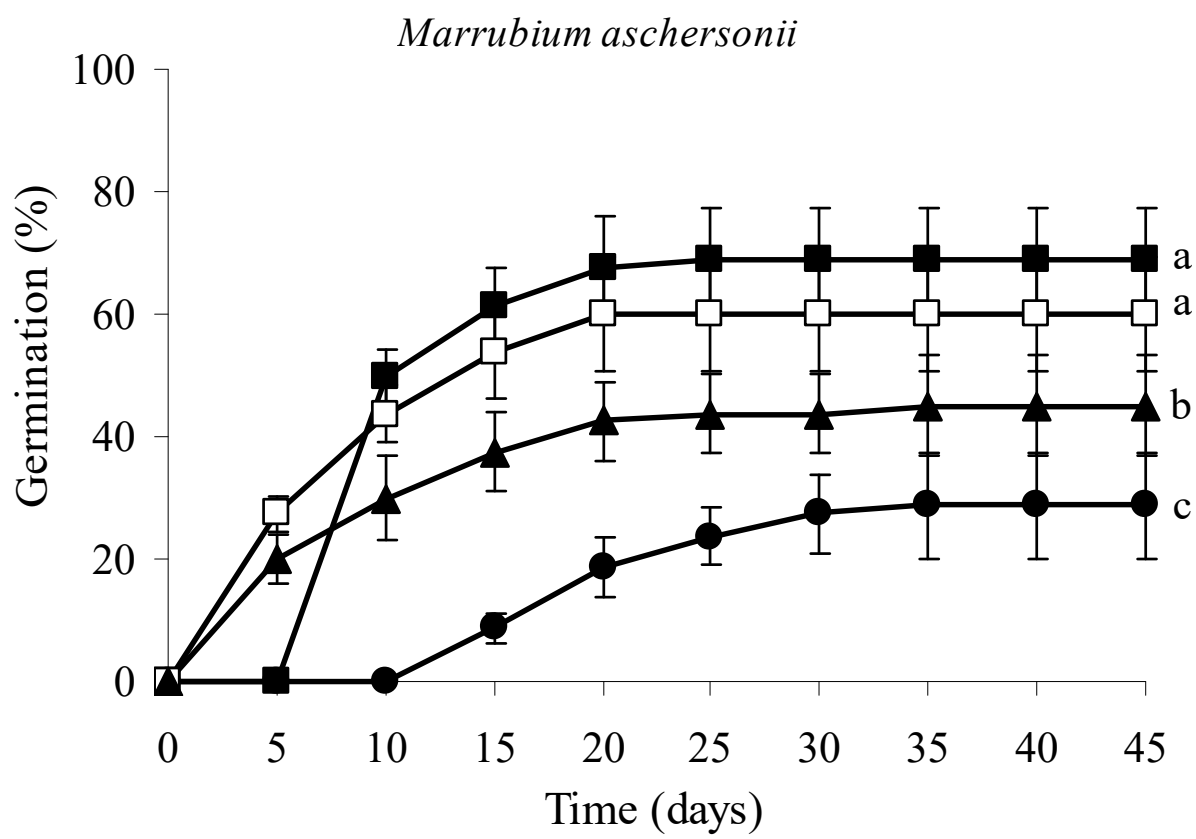

Figure 6. Cumulative germination percentage diagrams of Marrubium aschersonii seeds incubated at different temperatures $\left(\bullet 10^{\circ} \mathrm{C}, \boldsymbol{\square} 15^{\circ} \mathrm{C}, \square 20^{\circ} \mathrm{C}\right.$, and $\left.\boldsymbol{\Delta} 25^{\circ} \mathrm{C}\right)$. Means are statistically different at $p<0.05$ when they do not share a common letter. The comparisons were made using the Duncan's test.

\subsection{Seedling Growth in Pilot Cultivation}

Fertilization of $M$. aschersonii affected positively the growth and development until flowering for both treatments compared to control (Table 3). More specifically, the INM fertilization scheme showed an increase for the shoot height (20\%), the number of leaves (79\%), the aboveground dry biomass (32\%), the photosynthetic rate (19\%) and the chlorophyll content (38\%) compared with the control. The ChF scheme also presented a similar increase $(5.4 \%, 51 \%, 25 \%, 106 \%$, and 30\% respectively). The INM resulted in a better growth of 
plants by producing $28 \%$ more leaves and $14.6 \%$ taller plants than the ChF scheme, and the latter had a greater photosynthetic rate $(87 \%)$ than INM. It is worth mentioning that the root dry biomass for $\mathrm{ChF}$ treatment was 37\% less than the control; the chlorophyll fluorescence $\left(\mathrm{F}_{\mathrm{v}} / \mathrm{F}_{\mathrm{m}}\right)$, the length, and the width of the leaves remained the same for all treatments. Between the two fertilizers, no significant difference was found in the chlorophyll content and the root collar diameter.

Table 3. Effect of fertilization (INM: integrated nutrient management fertilizers; ChF: chemical fertilizers) on morphological and physiological characteristics of Marrubium aschersonii seedlings.

\begin{tabular}{|c|c|c|c|}
\hline Characteristics & Control & INM & ChF \\
\hline Shoot height $(\mathrm{cm})$ & $35.75 \pm 7.55^{\mathrm{a}}$ & $43.06 \pm 5.37^{\mathrm{a}}$ & $37.69 \pm 5.94^{\mathrm{a}}$ \\
\hline Root collar diameter (mm) & $4.03 \pm 0.39^{b}$ & $4.57 \pm 0.40^{\mathrm{a}}$ & $4.54 \pm 0.26^{\mathrm{a}}$ \\
\hline Number of leaves & $39.25 \pm 7.36^{c}$ & $70.12 \pm 5.19^{a}$ & $59.37 \pm 6.09^{b}$ \\
\hline Leaf length $(\mathrm{cm})$ & $3.12 \pm 0.42^{\mathrm{a}}$ & $3.04 \pm 0.40^{\mathrm{a}}$ & $3.14 \pm 0.73^{\mathrm{a}}$ \\
\hline Leaf width $(\mathrm{cm})$ & $2.66 \pm 0.35^{\mathrm{a}}$ & $2.50 \pm 0.29^{a}$ & $2.71 \pm 0.49^{a}$ \\
\hline Root dry biomass (g) & $1.10 \pm 0.19^{\mathrm{a}}$ & $1.00 \pm 0.12^{\mathrm{a}}$ & $0.69 \pm 0.16^{b}$ \\
\hline Above ground dry biomass (g) & $3.24 \pm 0.49^{b}$ & $4.29 \pm 0.60^{\mathrm{a}}$ & $4.05 \pm 0.73^{\mathrm{ab}}$ \\
\hline Photosynthetic rate $\left(\mu \mathrm{mol} \mathrm{m}{ }^{-2} \mathrm{~s}^{-1}\right)$ & $3.48 \pm 0.28^{c}$ & $4.15 \pm 0.49^{b}$ & $7.18 \pm 0.40^{\mathrm{a}}$ \\
\hline Chlorophyll content & $19.16 \pm 2.35^{b}$ & $26.49 \pm 1.69^{a}$ & $24.93 \pm 2.31^{\mathrm{a}}$ \\
\hline Chlorophyll fluorescence $\left(\mathrm{F}_{\mathrm{v}} / \mathrm{F}_{\mathrm{m}}\right)$ & $0.719 \pm 0.028^{a}$ & $0.741 \pm 0.017^{\mathrm{a}}$ & $0.725 \pm 0.013^{\mathrm{a}}$ \\
\hline
\end{tabular}

Means \pm standard deviation values are provided. Values in the same row followed by the same letter were not significantly different $(p>0.05)$ according to Duncan's test.

\subsection{Macro- and Micronutrient Content}

The macronutrient content of the $M$. aschersonii leaves for INM treatment was remarkable for the absorption of nitrogen, potassium, magnesium, and calcium compared with the control $(65 \%, 10 \%, 6 \%$, and $9 \%$, respectively). The ChF treatment also showed a greater content of nitrogen at $46 \%$, and an increase in potassium at $5 \%$ but also reduced values for calcium and magnesium at $10 \%$ and $9 \%$, respectively. Sodium was the only macronutrient with higher values with regards to the control and the fertilization treatments. It is worth mentioning that the phosphorous absorption was almost the same for all treatments (Table 4). The micronutrient content of the M. aschersonii leaves in the control plants showed much better absorption than fertilization treatments, except for the absorption of copper, which was 35 times greater for the INM treatment compared to the control. With regards to iron and zinc, the highest Fe and $\mathrm{Zn}$ concentrations were reported in unfertilized plants (Table 5).

Table 4. Macronutrient concentration in the leaves of Marrubium aschersonii young plants.

\begin{tabular}{ccccccc}
\hline Treatment & $\mathbf{N}(\%)$ & $\mathbf{P}(\mathbf{m g} / \mathbf{g r})$ & $\mathbf{K}(\mathbf{m g} / \mathbf{g r})$ & $\mathbf{C a}(\mathbf{m g} / \mathbf{g r})$ & $\mathbf{M g}(\mathbf{m g} / \mathbf{g r})$ & $\mathbf{N a}(\mathbf{m g} / \mathbf{g r})$ \\
\hline Control & $1.84^{\mathrm{c}}$ & $2.40^{\mathrm{a}}$ & $18.87^{\mathrm{c}}$ & $9.54^{\mathrm{c}}$ & $5.09^{\mathrm{a}}$ & $3.74^{\mathrm{a}}$ \\
Chemical fertilizer & $2.68^{\mathrm{b}}$ & $2.38^{\mathrm{a}}$ & $19.81^{\mathrm{b}}$ & $8.70^{\mathrm{b}}$ & $4.65^{\mathrm{b}}$ & $3.00^{\mathrm{c}}$ \\
$\begin{array}{c}\text { Integrated nutrient } \\
\text { management }\end{array}$ & $3.03^{\mathrm{a}}$ & $2.38^{\mathrm{a}}$ & $20.85^{\mathrm{a}}$ & $10.11^{\mathrm{a}}$ & $5.51^{\mathrm{a}}$ & $3.48^{\mathrm{b}}$
\end{tabular}

Within the same column, the means are statistically different at $p<0.05$ when they do not share a common letter The comparisons were made using the Duncan's test.

Table 5. Micronutrient concentration in the leaves of Marrubium aschersonii young plants.

\begin{tabular}{ccccc}
\hline Treatment & Fe (ppm) & Mn (ppm) & Zn (ppm) & Cu (ppm) \\
\hline Control & $485.69^{\mathrm{a}}$ & $90.21^{\mathrm{a}}$ & $51.31^{\mathrm{a}}$ & $7.08^{\mathrm{b}}$ \\
$\begin{array}{c}\text { Chemical fertilizer } \\
\text { Integrated nutrient }\end{array}$ & $224.73^{\mathrm{b}}$ & $82.89^{\mathrm{a}}$ & $31.27^{\mathrm{c}}$ & $3.53^{\mathrm{b}}$ \\
management & $254.60^{\mathrm{b}}$ & $55.90^{\mathrm{b}}$ & $37.50^{\mathrm{b}}$ & $244.86^{\mathrm{a}}$ \\
\hline
\end{tabular}

Within the same column, the means are statistically different at $p<0.05$ when they do not share a common letter The comparisons were made using the Duncan's test. 


\section{Discussion}

\subsection{Molecular Authentication (DNA Barcoding) of M. aschersonii}

Six chloroplast DNA markers and a nuclear ribosomal DNA marker were selected for molecular barcoding of $M$. aschersonii, and they were used to identify the genetic distinction among Marrubium taxa, thus providing a reference genetic DNA profile in GenBank. The $\operatorname{trn} \mathrm{L} / \operatorname{trn} \mathrm{F}$ molecular marker was the most useful for Marrubium taxa identification, providing 83 accessions from 28 different species of the genus Marrubium [2,5]. The closest species to $M$. aschersonii using $\operatorname{trn} \mathrm{L} / \operatorname{trn} \mathrm{F}$ is the South and Central Mediterranean taxon M. alysson (MH685077) and the north-west African taxon M. alyssoides (MH685076), both with a 6 bp difference (Figure 3) [5]. The $t r n \mathrm{~L} / \mathrm{trnF}$ molecular marker has previously been used in conjunction with four more plastid and nuclear molecular markers to confirm the monophyly of tribe Marrubieae and the proposed distinction of the five closely related genera Moluccella, Acanthoprasium, Marrubium, Ballota, and Pseudodictamnus within the tribe Marrubieae [2,5]. It is worth noticing the analysis of DNA sequences for the $r b c \mathrm{~L}$ molecular marker and the species blasted to $M$. aschersonii. Two of the accessions characterized as M. vulgare (U28875 and HM590056) revealed high dissimilarities (18 bp) compared to $M$. aschersonii but also to ten other $r b c \mathrm{~L}$ DNA sequences of $M$. vulgare (14 bp), and therefore should be checked and experimented again [4]. The mat $\mathrm{K}$ and $t r n \mathrm{H} / p s b \mathrm{~A}$ molecular markers have been widely used for many plants [56], and they have also been used for the identification of some Marrubium species [6,57]. The application of the matK marker to $M$. aschersonii was matched and compared to five Marrubium species and the $t r n \mathrm{H} / p s b \mathrm{~A}$ marker to three Marrubium species with the $25 \mathrm{bp}$ deletion to $M$. crassidens being the most important (Table 2). The rpoC1 [58] and petB/petD [59] markers did not match to any Marrubium DNA sequences, and, therefore, these DNA sequences delivered new sequence datasets for investigations related to Marrubium taxa. Although two accessions of $M$. crassidens and $M$. supinum [60] for the 18S/26S nrDNA molecular marker were deposited in GenBank, it was not feasible to identify nucleotide similarities with $M$. aschersonii; instead, it was found to be matched with Ballota nigra (MK909579, 87\% similarity) [61].

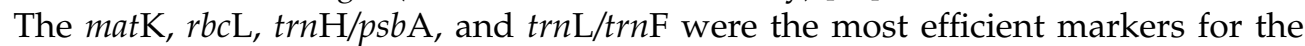
molecular characterization of $M$. aschersoni. Moreover, the $18 \mathrm{~S}-26 \mathrm{~S}, r p o \mathrm{C} 1$ and $p e t \mathrm{~B} / p e t \mathrm{D}$ are reported herein as promising new DNA molecular markers for the genus Marrubium. All of the above-mentioned target genes/genomic areas are generally conserved in all plants; therefore, they may be used to define single nucleotide polymorphisms (SNPs) serving as fingerprints of each particular $M$. aschersonii individual, and they may also provide accurate information for genetic identification of a new Marrubium species in the medicinal-cosmetic, agro-alimentary, or ornamental-horticultural industries.

\subsection{GIS-Facilitated Seed Germination}

The seeds of $M$. aschersonii exhibited high germination percentages without any pretreatments. In the present study, seed germination varied along a temperature gradient; thus, seed germination is temperature-related. Specifically, the M. aschersonii seeds germinated optimally in a narrow range of constant temperatures of $15-20{ }^{\circ} \mathrm{C}$. From the GIS-derived ecological profile of $M$. aschersonii, it was shown that these temperatures prevail in mid- to late autumn (October and November) in the natural locations of $M$. aschersonii. Furthermore, during these months, the mean precipitation in wild habitats of $M$. aschersonii starts increasing to $54.58 \mathrm{~mm}$ and $60.00 \mathrm{~mm}$, respectively. In this way, the seeds of the target species probably take advantage of suitable conditions. However, the narrow range of suitable temperatures for germination may be so because in the wet season the amount of precipitation is not very high compared to other regions (precipitation of wettest quarter $=196.75 \mathrm{~mm}$ ); therefore, $M$. aschersonii has probably developed an evolutionary specialization in the specific temperature range for its optimal germination. However, seeds of other Marrubium species such as M. vulgare can germinate over a wide temperature range, and their highest germination was observed under a $25 / 20^{\circ} \mathrm{C}$ (day/night) alternating temperature regime [62]. Furthermore, this temperature range between $15-20{ }^{\circ} \mathrm{C}$ has been 
referred to as optimal for seed germination for many Mediterranean species $[63,64]$. Fundamental studies [65] refer that temperature is a major environmental factor responsible for the timing of germination and that some species have a specific temperature range for seed germination. Therefore, the regulation of germination by temperature acts as a mechanism that allows the $M$. aschersonii seeds to germinate under favorable environmental conditions for seedling establishment and survival. $M$. aschersonii appeared to be sensitive to the incubation temperature, since the increase in temperature to $25{ }^{\circ} \mathrm{C}$ resulted in a significant decrease in germinated seeds. This fact may be considered as a closer adaptation of this species to its natural environment. Furthermore, the rapid germination of $M$. aschersonii seeds may be considered as an adaptation mechanism to avoid the dry unfavorable conditions for seedlings' growth. Thus, rapid germination may ensure the rapid establishment of seedlings in a period where soil maintains adequate moisture.

\subsection{M. aschersonii Seedling Growth and Response in Fertilization}

The study herein reported for the first time the cultivation of $M$. aschersonii examining the effect of fertilization (chemical and integrated nutrient management fertilizers compared to control plants with no fertilization). Generally, it is known that fertilizers can help to maintain a relatively high photosynthetic rate in plant leaves [66]. Thus, in our experiments with $M$. aschersonii the photosynthetic rate was increased when chemical fertilization was used. Of course, integrated nutrient management also increased the photosynthetic rate compared to control plants. These findings align with the general trend inferring that the application of fertilizers may enhance plant photosynthesis and the subsequent plant production $[67,68]$. However, it should be noted that the reasonable use of $\mathrm{N}$ can increase the potential activity and photochemical efficiency of PSII but may reduce qN, thereby improving the photosynthetic performance [69], which means that only rational application of $\mathrm{N}$ fertilizer can improve the photosynthetic efficiency [70]. In the same trend, it has been reported that $\mathrm{P}$ fertilization promotes nutrient uptake as well as nutrient transportation, and thus improves plant growth, dry matter accumulation, and light-use efficiency in plants [71].

The plants' chlorophyll content is in general positively correlated with both chemical and INM fertilizer application [72-74]. On the other hand, chlorophyll content can also be used as an indicator for reducing fertilizers, especially $\mathrm{N}$, as well as for determining the health of the free-of-stress cultivated plants [74]. In the M. aschersonii cultivated herein, the foliar application of both fertilizers contributed to higher chlorophyll values compared to control plants (no fertilizer). Regarding the chlorophyll fluorescence measurement, the quantum yield of photosystem PSII $\left(\mathrm{F}_{\mathrm{v}} / \mathrm{F}_{\mathrm{m}}\right)$ is the most frequently evaluated parameter [75]. In normally developing plant leaves of cultivated plants, the value of $F_{\mathrm{v}} / \mathrm{F}_{\mathrm{m}}$ usually ranges from 0.74 to 0.85 [76]. The results of this study concerning $M$. aschersonii indicated values for this parameter at the lower edge of the normally expected range. Previous studies [75] report that $\mathrm{F}_{\mathrm{v}} / \mathrm{F}_{\mathrm{m}}$ values may decrease in the presence of stressing factors. However, our observations and measurements in the pilot $M$. aschersonii cultivation were not able to indicate symptoms of stress conditions, and the cultivated plants developed well and flowered within the first year. Thus, it may be plausible that in some endemic species that are naturally adapted to survive in extremely difficult situations in their wild habitat the expected normal values reported by Lichtenthaler et al. [77] may be naturally shifted towards lower levels of $\mathrm{F}_{\mathrm{v}} / \mathrm{F}_{\mathrm{m}}$. Support for this assumption is contributed to by the more or less similar chlorophyll fluorescence values across all treatments in M. aschersonii, as well as the increased chlorophyll content in the treatments with fertilization application, which were detected.

The comparison of INM and ChF fertilization treatments against the control (no fertilization) showed many positive aspects, except the micronutrient absorption of Fe, $\mathrm{Zn}$, and Mn. The higher values of INM in the shoot height, the number of leaves, the aboveground dry biomass, and the chlorophyll content are fundamental cultivation targets 
in agriculture, suggesting the use of the INM scheme by foliar application as an effective cultivation protocol for M. aschersonii.

\subsection{Re-Evaluation of Feasibility and Readiness Timescale for the Sustainable Exploitation of M. aschersonii}

The knowledge and data generated herein for $M$. aschersonii should be taken into consideration to re-evaluate the feasibility for value-chain creation for this taxon (Level II evaluation after Krigas et al. [25]). After such re-evaluation of the attributes reported in our previous investigation [25], the feasibility for value-chain creation for M. aschersonii was considerably improved from $26.39 \%$ to $48.61 \%$, thus upgrading this taxon from the very low or lowest class to the lower to average class $(>35-50 \%)$. The difference in the Level II re-evaluation was generated due to the increased ex situ conservation (score 3: two stored accessions in two different institutions); the development of the seed propagation protocol (score 6 compared to 0$)$; the high germination rate achieved $(68.75 \%$, which is equivalent to score 5 compared to 0 ); the documented knowledge on species-specific cultivation needs (score 6 compared to 0 ); and the development of the species-specific cultivation protocol (score 6 compared to 0 ). This Level II re-evaluation indicates, furthermore, an upgrade in terms of the readiness timescale for sustainable exploitation regarding $M$. ascersonii (Level III evaluation according to Krigas et al. [25]); the latter was previously assessed as "indeterminable" [25]; this was upgraded herein to "achievable in the long-term" (class; $>35-50 \%$ ) but in fact, is very close to "achievable in medium-term" (class: $>50-55 \%$ ).

\section{Conclusions}

This study produced for the first time a detailed ecological profiling using Geographical Information Systems (GIS), which may provide insight on the abiotic environmental conditions that $M$. ascheronii requires in its wild habitats, informing at the same time whether such conditions can be imitated during cultivation and acclimatization in the man-made environment [31,39]. This profiling was particularly useful to understand the effect of the temperature on the seed germination of $M$. aschersonii and can be further exploited to produce detailed species-specific cultivation guidelines [31,39]. Furthermore, effective seed propagation of $M$. aschersonii as firstly reported herein can be perceived as a basic step enabling both in situ conservation efforts and ex situ conservation or sustainable exploitation strategies for this local endemic species of Tunisia [25,31,39]. The molecular authentication (DNA barcoding) of $M$. aschersonii, which was also first reported herein, may facilitate traceability in product design including parts of $M$. aschersonii. When taken all together, along with the first-time detected effects of chemical and integrated nutrient management fertilizers on the growth and pilot cultivation of $M$. aschersonii, seedlings are able to bridge important extant research gaps that hindered to date the conservation efforts and/or the sustainable exploitation for this local endemic plant of Tunisia with promising medicinal-cosmetic [26] or agro-alimentary potential [29] and ornamental-horticultural value [25]. Undoubtedly, coordinated efforts, domestic legislative instruments (e.g., extinction risk assessments at the national scale with IUCN criteria and protection acts for priority species of flora) as well as more applied research (e.g., vegetative propagation, pilot cultivations, agroprocessing aspects, etc.) are needed prior to attempts to attract stakeholder attention and to create an effective value chain for this highly promising species.

Author Contributions: Conceptualization, S.H., N.K. and G.T.; data curation, N.K., I.A., G.T., A.K., M.L., W.M.-K., M.E.H., S.K., M.A.S., E.K., V.G., E.P. (Eias Pipinis), E.P. (Evgenia Papaioannou) and S.B.; formal analysis, G.T., E.P. (Eias Pipinis), E.P. (Evgenia Papaioannou), N.K., I.A., S.K. and S.H.; funding acquisition, N.K., M.E.H. and S.B.; investigation, N.K., S.H., I.A., V.G., E.P. (Elias Pipinis), E.P. (Evgenia Papaioannou), S.K., A.K., M.L., W.M.-K., Z.G.-G., F.L., M.E.H., M.A.S., E.K., G.T. and S.B.; methodology, N.K., S.H., E.P. (Evgenia Papioannou), E.P. (Elias Pipinis), S.K., I.A., V.G., M.A.S., A.K., M.L., W.M.-K., Z.G.-G., F.L., M.E.H., G.T. and S.B.; project administration, N.K.; resources, N.K., M.E.H., S.H. and S.K.; software, N.K., I.A. and E.P. (Eias Pipinis); supervision, N.K., S.H. and G.T.; validation, I.A., V.G., E.K., E.P. (Eias Pipinis), E.P. (Evgenia Papioannou), A.K., M.L., W.M.-K., M.A.S., 
Z.G.-G., F.L., G.T., M.E.H. and S.B.; visualization, N.K., I.A., S.B., V.G., E.P. (Eias Pipinis), Z.G.-G. and S.K.; writing-original draft, E.P., S.H., N.K., I.A., G.T. and S.B.; writing-review and editing, all authors. All authors have read and agreed to the published version of the manuscript.

Funding: This research was supported by the ARIMNet2 2017 Transnational Joint Call through the MULTI-VAL-END project “Multifaceted Valorisation of single-country Endemic plants of Crete, Greece, Tunisia and Rif, Morocco for sustainable exploitation in the agro-alimentary, horticulturalornamental and medicinal-cosmetic sectors" and was co-funded by the Hellenic Agricultural Organization Demeter of Greece, the State Secretariat for Higher Education and Scientific Research (SEESRS) of Morocco and the Ministry of Higher Education and Scientific Research (Ministère de l'Enseignement Supérieur et de la Recherche Scientifique, MESRS), Republic of Tunisia. ARIMNet2 (ERA-NET) has received funding from the European Union's Seventh Framework Program for research, technological development, and demonstration, under grant agreement no. 618127.

Institutional Review Board Statement: Not applicable.

Informed Consent Statement: Not applicable.

Data Availability Statement: The data presented in this study are available on request from the corresponding authors.

Acknowledgments: The authors would like to thank the anonymous reviewers for their valuable comments and suggestions.

Conflicts of Interest: The authors declare no conflict of interest.

\section{References}

1. Meyre-Silva, C.; Cechinel-Filho, V. A review of the chemical and pharmacological aspects of the genus Marrubium. Curr. Pharm. Des. 2010, 16, 3503-3518. [CrossRef] [PubMed]

2. Siadati, S.; Salmaki, Y.; Saeidi, M.S.; Weigend, M. Untangling the generic boundaries in tribe Marrubieae (Lamiaceae: Lamioideae) using nuclear and plastid DNA sequences. Taxon 2018, 67, 770-783. [CrossRef]

3. Wink, M.; Kaufmann, M. Phylogenetic relationships between some members of the Subfamily Lamioideae (Family Labiatae) inferred from nucleotide sequences of the $r b c$ L gene. Bot. Acta. 1995, 109, 139-148. [CrossRef]

4. Elsherbeny, A.E. DNA barcoding of some medicinal plants, family Labiatae. Egypt. J. Exp. Biol. 2016, 12, 175-180. [CrossRef]

5. Scheen, A.C.; Bendiksby, M.; Ryding, O.; Mathiesen, C.; Albert, V.A.; Lindqvist, C. Molecular phylogenetics, character evolution, and suprageneric classification of Lamioideae (Lamiaceae). Ann. Missouri Bot. Gard. 2010, 97, 191-217. [CrossRef]

6. Roy, T.; Lindqvist, C. New insights into evolutionary relationships within the subfamily Lamioideae (Lamiaceae) based on pentatricopeptide repeat (PPR) nuclear DNA sequences. Amer. J. Bot. 2015, 102, 1721-1735. [CrossRef]

7. Marzouk, R.I.; El-Darier, S.M.; Nour, I.H.; Kamal, S.A. Numerical taxonomic study of Marrubium L. (Lamiaceae) in Egypt. Catrina 2015, 13, 25-35. Available online: https:/ / cat.journals.ekb.eg/article_18376.html (accessed on 30 December 2021).

8. Salehi, N.; Kharazian, N.; Shiran, B. Genetic diversity of Marrubium species from Zagros region (Iran), using inter simple sequence repeat molecular marker. J. Sci. Islamic Repub. Iran. 2018, 29, 7-19. [CrossRef]

9. Sanna, G.; Farci, P.; Busonera, B.; Murgia, G.; La Colla, P.; Giliberti, G. Antiviral properties from plants of the Mediterranean flora. Nat. Prod. Res. 2015, 29, 2065-2070. [CrossRef]

10. Hashemi, M.; Kharazian, N. Identification of flavonoids from Marrubium and Ballota species (Lamiaceae) and determination of chemotaxonomic markers using High Performance Liquid Chromatography Mass Spectrometer. J. Sci. Islam Repub. Iran 2021, 32, 305-320. [CrossRef]

11. Zaabat, N.; Hay, A.E.; Michalet, S.; Darbour, N.; Bayet, C.; Skandrani, I.; Chekir-Ghedira, L.; Akkal, S.; Dijoux-Franca, M.G. Antioxidant and antigenotoxic properties of compounds isolated from Marrubium deserti de Noé. Food Chem. Toxicol. 2011, 49, 3328-3335. [CrossRef] [PubMed]

12. Hamdaoui, B.; Wannes, W.A.; Marrakchi, M.; Brahim, N.B.; Marzouk, B. Essential oil composition of two Tunisian Horehound species: Marrubium vulgare L. and Marrubium aschersonii Magnus. J. Essent. Oil Bear. Plants 2013, 16, 608-612. [CrossRef]

13. Hammami, S.; Li, Z.; Huang, M.; El Mokni, R.; Dhaouadi, H.; Yin, S. New bioactive labdane diterpenoids from Marrubium aschersonii. Nat. Prod. Res. 2016, 30, 2142-2148. [CrossRef] [PubMed]

14. Zhang, J.S.; Zou, Y.H.; Zhao, J.J.; Chen, Y.; Bao, J.M.; Tang, G.H. Three new diterpenoids from Marrubium aschersonii. Phytochem. Lett. 2016, 16, 241-244. [CrossRef]

15. De Jesus, R.A.P.; Cechinel-Filho, V.; Oliveira, A.E.; Schlemper, V. Analysis of the antinociceptive properties of marrubiin isolated from Marrubium vulgare. Phytomedicine 2000, 7, 111-115. [CrossRef]

16. Sahpaz, S.; Garbacki, N.; Tits, M.; Bailleul, F. Isolation and pharmacological activity of phenylpropanoid esters from Marrubium vulgare. J. Ethnopharmacol. 2002, 79, 389-392. [CrossRef]

17. Stulzer, H.K.; Tagliari, M.P.; Zampirolo, J.A.; Cechinel-Filho, V.; Schlemper, V. Antioedematogenic effect of marrubiin obtained from Marrubium vulgare. J. Ethnopharmacol. 2006, 108, 379-384. [CrossRef] 
18. Wiesner, J. Assessment Report on Marrubium vulgare L., Herba. EMA/HMPC/604273/2012, Committee on Herbal Medicinal Products (HMPC), European Medicines Agency. 2013. Available online: https:/ /www.ema.europa.eu/en/documents/herbalreport/final-assessment-report-marrubium-vulgare-1-herba-first-version_en.pdf (accessed on 29 December 2021).

19. Pottier-Alapetite, G. Angiosperrnes Dicotylédones: Apétales-dialypétales-gamopétales. Première et deuxième partie.-Ouvrage publié par le Ministère de l'Enseignement Supérieur et de la Recherche Scientifique et le Ministère de l'Agriculture-Tunisie. Flore Tunisie 1981, 1190.

20. Grigoriadou, K.; Krigas, N.; Lazari, D.; Maloupa, E. Chapter 4-Sustainable use of Mediterranean medicinal-aromatic plants. In Feed Additives; Florou-Paneri, P., Christaki, E., Giannenas, I., Eds.; Elsevier Academic Press: Amsterdam, The Netherlands, 2020; pp. 57-74. ISBN 9780128147009. [CrossRef]

21. Dadach, M. Recherche des Conditions Optimales de la Germination des Graines de Quelques Labiées du Mont de Tessala (Ouest Algérien) et Perspectives de Conservation. Ph.D. Thesis, Université Djillali Liabes de Sidi Bel Abbes, Sidi Bel Abbes, Algérie, October 2016.

22. Belmehdi, O.; El Harsal, A.; Benmoussi, M.; Laghmouchi, Y.; Skali Senhaji, N.; Abrini, J. Effect of light, temperature, salt stress and $\mathrm{pH}$ on seed germination of medicinal plant Origanum elongatum (Bonnet) Emb. \& Maire. Biocatal. Agric. Biotechnol. 2018, 16, 126-131. [CrossRef]

23. Flores-Enríquez, V.; Castillo, G.; Collazo-Ortega, M. Experimental seed germination for ex situ conservation of Mexican Podostemaceae. Bot. Sci. 2019, 97, 413-422. [CrossRef]

24. Grigoriadou, K.; Sarropoulou, V.; Krigas, N.; Maloupa, E.; Tsoktouridis, G. GIS-facilitated effective propagation protocols of the Endangered local endemic of Crete Carlina diae (Rech. f.) Meusel and A. Kástner (Asteraceae): Serving ex-situ conservation needs and its future sustainable exploitation as an ornamental. Plants 2020, 9, 1465. [CrossRef] [PubMed]

25. Krigas, N.; Tsoktouridis, G.; Anestis, I.; Khabbach, A.; Libiad, M.; Megdiche-Ksouri, W.; Ghrabi-Gammar, Z.; Lamchouri, F.; Tsiripidis, I.; Tsiafouli, M. Exploring the potential of neglected local endemic plants of three Mediterranean regions in the ornamental sector: Value chain feasibility and readiness timescale for their sustainable exploitation. Sustainability 2021, 13, 2539. [CrossRef]

26. Bourgou, S.; Ben, I.H.J.; Karous, O.; Megdiche-Ksouri, W.; Ghrabi-Gammar, Z.; Libiad, M.; Khabbach, A.; El Haissoufi, M.; Lamchouri, F.; Greveniotis, V.; et al. Medicinal-cosmetic potential of the local endemic plants of Crete (Greece), Northern Morocco and Tunisia: Priorities for conservation and sustainable exploitation of neglected and underutilized phytogenetic resources. Biology 2021, 10, 1344. [CrossRef] [PubMed]

27. Fanourakis, D.; Paschalidis, K.; Tsaniklidis, G.; Tzanakakis, V.A.; Bilias, F.; Samara, E.; Liapaki, E.; Juini, M.; Ipsilantis, I.; Maloupa, E.; et al. Pilot cultivation of the local endemic Cretan marjoram Origanum microphyllum (Benth.) Vogel (Lamiaceae): Effect of fertilizers on growth and herbal quality features. Agronomy 2022, 12, 94. [CrossRef]

28. Hatzilazarou, S.; El Haissoufi, M.; Pipinis, E.; Kostas, S.; Libiad, M.; Khabbach, A.; Lamchouri, F.; Bourgou, S.; Megdiche-Ksouri, W.; Ghrabi-Gammar, Z.; et al. GIS-facilitated seed germination and multifaceted evaluation of the endangered Abies marocana Trab. (Pinaceae): Enabling conservation and sustainable exploitation. Plants 2021, 10, 2606. [CrossRef] [PubMed]

29. Libiad, M.; Khabbach, A.; El Haissoufi, M.; Anestis, I.; Lamchouri, F.; Bourgou, S.; Megdiche-Ksouri, W.; Ghrabi-Gammar, Z.; Greveniotis, V.; Tsiripidis, I.; et al. Agro-alimentary potential of the neglected and underutilized local endemic plants of Crete (Greece), Rif-Mediterranean coast of Morocco and Tunisia: Perspectives and challenges. Plants 2021, 10, 1770. [CrossRef]

30. Maloupa, E.; Karapatzak, E.; Ganopoulos, I.; Karydas, A.; Papanastasi, K.; Kyrkas, D.; Yfanti, P.; Nikisianis, N.; Zahariadis, A.; Kosma, I.S.; et al. Molecular Authentication, Phytochemical evaluation and asexual propagation of wild-growing Rosa canina L. (Rosaceae) genotypes of Northern Greece for sustainable exploitation. Plants 2021, 10, 2634. [CrossRef] [PubMed]

31. Paschalidis, K.; Fanourakis, D.; Tsaniklidis, G.; Tzanakakis, V.A.; Bilias, F.; Samara, E.; Kalogiannakis, K.; Debouba, F.J.; Ipsilantis, I.; Tsoktouridis, G.; et al. Pilot cultivation of the vulnerable Cretan endemic Verbascum Arcturus L. (Scrophulariaceae): Effect of fertilization on growth and quality features. Sustainability 2021, 13, 14030. [CrossRef]

32. Macdonald, B. Practical Woody Plant Propagation for Nursery Growers; Timber Press Inc.: Portland, OR, USA, 2006 ; p. 669.

33. Kostopoulou, P.; Radoglou, K.; Dini-Papanastasi, O.; Spyroglou, G. Enhancing planting stock quality of Italian cypress (Cupressus sempervirens L.) by pre-cultivation in mini-plugs. Ecol. Eng. 2010, 36, 912-919. [CrossRef]

34. O'Reill, C.; Arnott, J.T.; Owens, J.N. Effects of photoperiod and moisture availability on shoot growth, seedling morphology, and cuticle and epicuticular wax features of container-grown western hemlock seedlings. Can. J. For. Res. 1989, 19, 122-131. [CrossRef]

35. Radoglou, K.M. Effect of environmental stress on planting stock and field performance. In Proceedings of the National Forestry Conference: Planting Stock of Woody Species, Thessaloniki, Greece, 28-29 January 1999; pp. 15-26.

36. Buendia Velazquez, M.V.; Lopez Lopez, M.A.; Cetina Alcala, V.M.; Diakite, L. Substrates and nutrient addition rates affect morphology and physiology of Pinus leiophylla seedlings in the nursery stage. iForest 2016, 10, 115-120. [CrossRef]

37. Oliet, J.; Planelles, R.; Artero, F.; Valverde, R.; Jacobs, D.F.; Segura, M. Field performance of Pinus halepensis planted in Mediterranean arid conditions: Relative influence of seedling morphology and mineral nutrition. New For. 2009, 37, 313-331. [CrossRef]

38. Villar-Salvador, P.; Puertolas, J.; Penuelas, J.L.; Planelles, R. Effect of nitrozen fertilization in the nursery on the drought and frost resistance of Mediterranean forest species. For. Syst. 2005, 14, 408-418. [CrossRef] 
39. Krigas, N.; Mouflis, G.; Grigoriadou, K. Conservation of important plants from the Ionian Islands at the Balkan Botanic Garden of Kroussia, N Greece: Using GIS to link the in situ collection data with plant propagation and ex situ cultivation. Biodivers. Conserv. 2010, 19, 3583-3603. [CrossRef]

40. Krigas, N.; Papadimitriou, K.; Mazaris, A.D. GIS and Ex-Situ Plant Conservation; Alam, B.M., Ed.; Application of Geographic Information Systems, InTechopen.com: Rijeka, Croatia, 2012; Available online: https://www.intechopen.com/chapters/40525 (accessed on 29 December 2021).

41. Cuénod, A. Flore Analytique et Synoptique de la Tunisie (Cryptogames Vasculaires, Gymnospermes et Monocotylédones); Office de l’Expérimentation et de la Vulgarisation Agricoles: Tunisie, Tunis, 1954.

42. Pottier-Alapetite, G. Flore de la Tunisie (Angiospermes-Dicotylédones); Publications Scientifiques Tunisiennes, Ministère de l'Enseignement supérieur et de la Recherche Scientifique, Ministère de l'Agriculture: Tunis, Tunisie, 1981.

43. Tsoktouridis, G.; Tsiamis, G.; Koutinas, N.; Mantell, S. Molecular detection of bacteria in plant tissues using universal 16S ribosomal DNA degenerated primers. Biotechnol. Biotechol. Equip. 2014, 28, 583-591. [CrossRef]

44. Tsoktouridis, G.; Krigas, N.; Sarropoulou, V.; Kampouropoulou, S.; Papanastasi, K.; Grigoriadou, K.; Menexes, G.; Maloupa, E. Micropropagation and molecular characterization of Thymus sibthorpii Benth. (Lamiaceae), an aromatic-medicinal thyme with ornamental value and conservation concern. In Vitro Cell. Dev. Biol. 2019, 55, 647-658. [CrossRef]

45. Van de Peer, Y. Phylogenetic inference based on distance methods. In The Phylogenetic Handbook: A Practical Approach to Phylogenetic Analysis and Hypothesis Testing; Lemey, P., Salemi, M., Vandamme, A.M., Eds.; Cambridge University Press: Cambridge, UK, 2009.

46. Tamura, K.; Stecher, G.; Kumar, S. MEGA11: Molecular Evolutionary Genetics Analysis Version 11. Mol. Biol. Evol. 2021, 38, 3022-3027. [CrossRef]

47. Richardson, A.D.; Duigan, S.P.; Berlyn, G.P. An evaluation of noninvasive methods to estimate foliar chlorophyll content. New Phytologist 2002, 153, 185-194. [CrossRef]

48. Cessna, S.; Demmig-Adams, B.; Adams, W.W., III. Exploring photosynthesis and plant stress using inexpensive chlorophyll fluorometers. J. Nat. Resourc. Life Sci. Educ. 2010, 39, 22-30. [CrossRef]

49. Allen, S.E.; Grimshaw, H.M.; Rowland, A.P. Chemical analysis. In Methods in Plant Ecology; Moore, P.D., Chapman, S.B., Eds.; Blackwell Scientific Publication: Oxford, UK, 1986; pp. 285-344.

50. Olsen, S.R.; Sommers, L.E. Phosphorus. In Methods of Soil Analysis Part 2 Chemical and Microbiological Properties; Page, A.L., Miller, R.H., Keeney, D.R., Eds.; American Society of Agronomy, Soil Science Society of America: Madison, WI, USA, 1982 ; pp. 403-430.

51. Bremmer, J.M.; Mulvaney, C.S. Nitrogen-total. In Methods of Soil Analysis. Part 2: Chemical and Microbial Properties, 2nd ed.; Page, A.L., Miller, R.H., Keeney, D.R., Eds.; American Society of Agronomy, Soil Science Society of America: Madison, WI, USA, 1982; pp. 595-624.

52. Klockars, A.; Sax, G. Multiple Comparisons; Sage Publications: Newbury Park, CA, USA, 1986; p. 87.

53. Snedecor, G.W.; Cochran, W.C. Statistical Methods, 7th ed.; The Iowa State University Press: Ames, IA, USA, $1980 ;$ p. 507.

54. Libiad, M.; Khabbach, A.; El Haissoufi, M.; Bourgou, S.; Megdiche-Ksouri, W.; Ghrabi-Gammar, Z.; Sharrock, S.; Krigas, N. Ex-situ conservation of single-country endemic plants of Tunisia and northern Morocco (Mediterranean coast and Rif region) in seed banks and botanic gardens worldwide. Kew Bull. 2020, 75, 46. [CrossRef]

55. Hollingsworth, P.M.; Forrest, L.L.; Spouge, J.L.; Hajibabaei, M.; Ratnasingham, S.; van der Bank, M.; Chase, M.W.; Cowan, R.S.; Erickson, D.L.; Fazekas, A.J.; et al. A DNA barcode for land plants. Proc. Natl. Acad. Sci. USA 2009, 106, 12794-12797. [CrossRef]

56. Kumar, M.; Chaudhary, V.; Sirohi, U.; Sharma, V.R.; Naresh, R.K. Application of molecular markers and their utility in genetic studies of floricultural crops: A review. Inter. J. Agric. Environ. Biotechnol. 2019, 12, 229-247. [CrossRef]

57. Theodoridis, S.; Stefanaki, A.; Tezcan, M.; Aki, C.; Kokkini, S.; Vlachonasios, K.E. DNA barcoding in native plants of the Labiatae (Lamiaceae) family from Chios Island (Greece) and the adjacent Cesme-Karaburun Peninsula (Turkey). Mol. Ecol. Resour. 2012, 12, 620-633. [CrossRef] [PubMed]

58. Chase, W.; Cowan, M.R.; Hollingsworth, M.; van den Berg, P.C.; Madriñán, S.; Petersen, G.; Seberg, O.; Jorgsensen, T.; Cameron, K.; Carine, M.; et al. A proposal for a standardized protocol to barcode all land plants. Taxon 2007, 56, 295-299. [CrossRef]

59. Löhne, C.; Borsch, T. Phylogenetic utility and molecular evolution of the petD group II intron in basal angio-sperms. Mol. Biol. Evol. 2005, 22, 317-332. [CrossRef]

60. Barber, J.C.; Francisco-Ortega, J.; Santos-Guerra, A.; Turner, K.G.; Jansen, R.K. Origin of Macaronesian sideritis L. (Lamioideae: Lamiaceae) inferred from nuclear and chloroplast sequence datasets. Mol. Phylogenet. Evol. 2002, 23, 293-306. [CrossRef]

61. Salmaki, Y.; Heubl, G.; Weigend, M. Towards a new classification of tribe Stachydeae (Lamiaceae): Naming clades using molecular evidence. Bot. J. Linn. Soc. 2019, 190, 345-358. [CrossRef]

62. Javaid, M.M.; Florentine, S.K.; Ali, H.H.; Chauhan, B.S. Environmental factors affecting the germination and emergence of white horehound (Marrubium vulgare L.): A weed of arid-zone areas. Rangel. J. 2018, 40, 47-54. [CrossRef]

63. Thanos, C.A.; Kadis, C.C.; Skarou, F. Ecophysiology of germination in the aromatic plants thyme, savory and oregano (Labiatae). Seed Sci. Res. 1995, 5, 161-170. [CrossRef]

64. Krichen, K.; Mariem, H.B.; Chaieb, M. Ecophysiological requirements on seed germination of a Mediterranean perennial grass (Stipa tenacissima L.) under controlled temperatures and water stress. S. Afr. J. Bot. 2014, 94, 210-217. [CrossRef]

65. Baskin, C.C.; Baskin, J.M. Seeds: Ecology, Biogeography, and Evolution of Dormancy and Germination, 2nd ed.; Academic Press: San Diego, CA, USA, 2014. 
66. Zou, T.X.; Dai, T.B.; Jiang, D. Effects of nitrogen and potassium application levels on flag leaf photosynthetic characteristics after anthesis in winter wheat. Acta Agron. Sin. 2007, 33, 1667-1673.

67. Kunzova, E.; Hejcman, M. Yield development of winter wheat over 50 years of FYM, N, P and K fertilizer application on black earth soil in the Czech Republic. Field Crops Res. 2009, 111, 226-234. [CrossRef]

68. Yang, Y.; Zhang, J.; Chen, L.; Ji, A.; Zhao, H.; Guo, P. Effects of fertilizer levels and plant density on chlorophyll contents, its fluorescence and grain yield of Setaria italica. Intern. J. Agric. Biol. 2018, 20, 737-744. [CrossRef]

69. Zhang, Y. Response characteristics of plant growth and leaf photochemical activity of sugar beet seedlings to different nitrogen application leaves. J. Nuclear Agric. Sci. 2013, 27, 1391-1400. [CrossRef]

70. Xiong, Z.R.C.; Zhongxiao, Y.; Xiahong, L.; Jing, L.; Minijia, H. Effects of nitrogen and density interaction on grain yield and nitrogen use efficiency of Sorghum. Crops 2018, 5, 110-115. [CrossRef]

71. Xiao, W.X.; Xie, F.T.; Zhang, H.J.; Wang, H.Y.; Wang, H. Effect of fertilizer and planting density on photosynthetic characteristics and yield of super-high- yielding soybean cultivar. Chin. J. Oil Crop Sci. 2009, 31, 190-195.

72. Najm, A.; Haj, M.R.; Hadi, S.; Fazeli, F.; Darzi, M.; Rahi, A. Effect of integrated management of nitrogen fertilizer and cattle manure on the leaf chlorophyll, yield, and tuber glycoalkaloids of agria potato. Commun. Soil Sci. Plant Anal. 2012, 43, 912-923. [CrossRef]

73. Kuo, Y.J. Effects of fertilizer type on chlorophyll content and plant biomass in common Bermuda grass. Afr. J. Agric. Res. 2015, 10, 3997-4000. [CrossRef]

74. Jafar, S.; Mehdi, T.M. Reducing nitrogen fertilizers with chlorophyll meter for determining health production. J. Env. Sci. Tech. 2020, 22, 103-111. [CrossRef]

75. Špulák, O.; Martincová, J.; Vitamvas, J.; Kunes, I. Effect of fertilization on chlorophyll activity, content of photosynthetically active pigments and nutrients in Carpathian birch leaves. Austrian J. For. Sci. 2014, 131, 23-44. Available online: https://www.researchgate.net/publication/269630072_Effect_of_fertilization_on_chlorophyll_activity_content_of_ photosynthetically_active_pigments_and_nutrients_in_Carpathian_birch_leaves (accessed on 30 December 2021).

76. Fiorentini, M.; Zenobi, S.; Giorgini, E.; Basili, D.; Conti, C.; Pro, C.; Monaci, E.; Orsini, R. Nitrogen and chlorophyll status determination in durum wheat as influenced by fertilization and soil management: Preliminary results. PLOS ONE 2019, 14, e0225126. [CrossRef] [PubMed]

77. Lichtenthaler, H.K.; Buschmann, C.; Knapp, M. How to correctly determine the different chlorophyll fluorescence parameters and the chlorophyll fluorescence decrease ratio R Fd of leaves with the PAM fluorometer. Photosynthetica 2005, 43, 379-393. [CrossRef] 